\title{
The marriage of chemokines and galectins as functional heterodimers
}

\author{
Philipp von Hundelshausen ${ }^{1,5}\left[\right.$ [Danin Wichapong ${ }^{2}$ [ $\cdot$ Hans-Joachim Gabius ${ }^{3} \cdot$ Kevin H. Mayo ${ }^{4}$
}

Received: 4 May 2021 / Revised: 5 October 2021 / Accepted: 22 October 2021 / Published online: 12 November 2021

(c) The Author(s) 2021

\begin{abstract}
Trafficking of leukocytes and their local activity profile are of pivotal importance for many (patho)physiological processes. Fittingly, microenvironments are complex by nature, with multiple mediators originating from diverse cell types and playing roles in an intimately regulated manner. To dissect aspects of this complexity, effectors are initially identified and structurally characterized, thus prompting familial classification and establishing foci of research activity. In this regard, chemokines present themselves as role models to illustrate the diversification and fine-tuning of inflammatory processes. This in turn discloses the interplay among chemokines, their cell receptors and cognate glycosaminoglycans, as well as their capacity to engage in new molecular interactions that form hetero-oligomers between themselves and other classes of effector molecules. The growing realization of versatility of adhesion/growth-regulatory galectins that bind to glycans and proteins and their presence at sites of inflammation led to testing the hypothesis that chemokines and galectins can interact with each other by protein-protein interactions. In this review, we present some background on chemokines and galectins, as well as experimental validation of this chemokine-galectin heterodimer concept exemplified with CXCL12 and galectin-3 as proofof-principle, as well as sketch out some emerging perspectives in this arena.
\end{abstract}

Keywords Cytokines · Glycoprotein $\cdot$ Inflammation $\cdot$ Lectin $\cdot$ Leukocytes

Philipp von Hundelshausen and Kevin H. Mayo share senior authorship.

Hans-Joachim Gabius passed away in August 2021.

Philipp von Hundelshausen

phundels@med.lmu.de

$\triangle$ Kevin H. Mayo

mayox001@umn.edu

1 Institute for Cardiovascular Prevention (IPEK), LudwigMaximilians-University Munich, 80336 Munich, Germany

2 Department of Biochemistry, Cardiovascular Research Institute Maastricht (CARIM), Maastricht University, 6229ER Maastricht, The Netherlands

3 Institute of Physiological Chemistry, Faculty of Veterinary Medicine, Ludwig-Maximilians-University, Munich, Germany

4 Department of Biochemistry, Molecular Biology and Biophysics, University of Minnesota Health Sciences Center, Minneapolis, MN 55455, USA

5 German Center for Cardiovascular Research (DZHK), Partner Site Munich Heart Alliance, Munich, Germany

\section{Introduction}

In order for single cells to form tissues and multicellular organisms, diverse types of "molecular glues" are required. On the biochemical level, homo- and heterotypic modes of recognition, along with the broad diversity of contacts with the extracellular matrix, bring cells together by a "cell adhesion code". Structural characterization of glycoproteins involved in this complex process has provided direction to shape the nomenclature for its components. For example, the term "integrin" was coined "for the 'integral' membrane protein complex linking the extracellular matrix to the cytoskeleton" [1]. Paradigmatically, the structural theme (i.e. the fold and sequence signature that makes interactions possible) leads to diversity in molecular ancestry such that families of recognition molecules have emerged [2-4]. In parallel with this diversification, information coding that underlies pattern recognition has been extended beyond a discussion of the complementarity between proteins.

Sugars of cellular glycoconjugates are now also being recognized as biochemical messages. Glycans that present docking sites for receptors (lectins) store information within a minimal space (a specific set of spatially related amino 
acid residues within the folded protein) and thus are ideal for serving as cell surface signals $[5,6]$. Protein-protein and protein-glycan interactions cooperate to ensure mechanical stability when building specific patterns. Of note, combinatorial permutations allow a glycoprotein (e.g. an integrin or extracellular matrix molecule like laminin or a lectican) to become involved in these types of molecular recognition that increase their applicability as cell biological tools. The engagement of integrins in such pairing covers the range from static to transient interactions, along with the ability to transmit outside-in signals [7, 8]. Along this route, integrin binding to a counter-receptor can account for modulating metabolic and transcriptional activities, apoptosis and growth, as well as for secretion of soluble mediators. These factors bring in a second and equally crucial means for cells to convey information. In principle, such secreted factors are essential for inter-cellular communication (without direct contact between surfaces). Here, we have used inflammation as a model system.

Considering the coordinated steps that allow leukocytes to home in on inflamed tissue, there is a distinct class of soluble factors that guides cellular movements within the transendothelial migration phase, i.e. the chemokines [9-11]. In fact, these small proteins are mediators of leukocyte recruitment [12], a starting point for thorough analysis of each family member and delineation of fundamental principles as expressed in the following statement: "Although many of the adhesion molecules and chemokines that direct leukocyte trafficking have been identified, there is still much to be discovered, particularly with regard to the persistence of leukocyte infiltration in chronic inflammation" [13]. Knowing what occurs among/between classes of various mediators may endow the microenvironment with hitherto unsuspected paired proteins with functional significance.

Apart from chemokines, one class of mediators that stands out from the population of regulators is the family of ga(lactoside-binding)lectins, i.e. galectins [14]. These mediators have been denoted as "exquisite modulators of the immune response" [13]. As broad-spectrum effectors of leukocyte activity and migration [15-17], galectins can serve as bridging molecules between both cells and cell surface glycoconjugates to construct highly ordered lattices in the membrane [18-25] and to act as sensors of damage- and pathogen-associated molecular patterns [26-28]. In this regard, elucidating their roles in inflammation deserves attention.

Our studies on both chemokine and galectin mediator classes have already resulted in discovering that expression of galectins and chemokines is correlated by a galectin-dependent enhancement of chemokine production and secretion. This intriguing phenomenon has been observed in various cell types, e.g. monocytes [29] or activated pancreatic stellate cells (that secreted the chemokine CXCL12 promoting pancreatic cancer cell invasiveness) [30, 31], rheumatoid synovial fibroblasts [32], osteoarthritic chondrocytes [33, 34], endothelial cells [35, 36] and bone marrow-derived dendritic cells [37]. Learning more about these protein mediator families, their structures and interacting partners are the bases for assessing whether there is more than just a galectin-induced upregulation of chemokine expression that connects these families and makes both classes available in the microenvironment.

\section{Cell migration}

One cellular elicitor function that chemokines and galectins have in common is cell migration and activation. Positioning cells within a tissue at predestined sites is fundamental to physiology, e.g. in embryonic development, tissue regeneration, and host defense. In these instances, signals provide direction to cell motion via chemoattractants as sensed by their cell receptors. Cells are thereby directed to various destinations by following chemoattractant gradients. The absolute concentration and temporal dynamics of a gradient determine the velocity and persistence of migrating cells and other signaling molecules that affect these parameters by regulating receptor desensitization [38]. Once one side of a cell senses presence of a chemoattractant, the cell becomes polarized with this initial contact side (forming the leading edge for cell movement) with protrusions extending towards the direction of cell migration [39], as shown in Fig. 1.

When in contact with a surface, polarized cells interact with adhesion molecules, such as integrins. Their binding to counter-receptors at the cell surface generates traction forces that promote relatively rapid locomotion. Even without these molecular handles, leukocytes can move around. If confined in a three-dimensional environment, leukocytes use (in addition to or in the absence of adhesion molecules) friction to the topographical particularities of a solid matrix to migrate [40]. To do so, however, the rearrangement of the actin cytoskeleton nestles closely to the substratum, thus generating retrograde shear forces sufficient to propel the

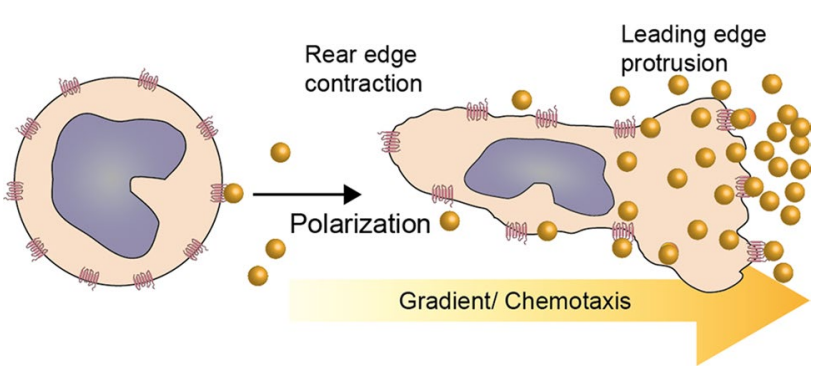

Fig. 1 Cartoon depiction of leukocyte polarization and migration given direction by a chemotactic gradient 
cell forward [40]. In the absence of a matrix (i.e. in solution), leukocytes swim using a breaststroke-like motion with cell protrusions which serve as paddles that are enriched in proteins [41].

Leukocytes routinely and randomly patrol cell surfaces and in tissues, an important surveillance that allows detection of pathogen invaders. It is assumed that cells 'understand' directional cues by sensing fields of chemoattractants, and it is via these processes that chemokines and galectins are the central mediators. Indeed in tissues, chemokines form gradients that enable haptotactic migration of leukocytes [42], and galectins (e.g. galectins-1, -3 and -8 (Gal-1, -3 and -8$)$ ) promote cell migration of immune cells [16], epithelial cells [43] and glioblastoma cells [44-46], respectively, as they can be suppressive in a context-dependent manner like Gal-8 with colon cancer cells [47].

\section{Chemokines}

The genesis of the molecular era of chemokines is attributed to several findings, one being the discovery of platelet factor 4 (PF4 or CXCL4), a structural proto-type chemokine that was purified by exploiting its high affinity for heparin [48]. Functionally, PF4 differs from most other chemokines by a lack of a high-affinity G-Protein Coupled Receptor (GPCR) and a lack of chemotactic activity [48-50]. From a functional perspective, the first human chemotactic factor, $\mathrm{MCP}-$ 1 , was isolated from supernatants of activated leukocytes and thus designated to be a member of a family of lymphokines or intercrines [51, 52]. Following its discovery, a steadily growing number of related small proteins $(\sim 8 \mathrm{kDa})$ were identified and placed into the so-called PF4 super-family (for a survey of human chemokines, please see Table 1).

Chemokine classification is based on the position of a highly conserved cysteine motif within the N-terminal sequence of the protein. In the two largest classes of chemokine, this motif consists of two cysteine residues either separated by a single variable amino acid residue (CXC family) or placed in tandem (CC family or RANTES/ SIS family) [53]. To avoid the use of several names for this family of chemotactic cytokines, the "Third International Symposium on Chemotactic Cytokines" held in 1992 in Baden (Austria) established the generic term "chemokine" [54].

From a genetics point of view, it was the gene of one of these small, inducible cytokines (I-309) that gave rise to the now commonly used gene name SCYAl, with $A$ being a classifier for the CC family and with the gene for Gro- $\alpha$ introducing the $\mathrm{B} / \mathrm{CXC}$ family $(S C Y B 1)$. In both mouse and human, these gene families occur in several clusters on distinct chromosomes. At that time, the molecular details of chemokine receptors were just beginning to emerge, such that in 1997 an NC-IUPHAR subcommittee on chemokine receptor nomenclature developed the idea of numbering signaling receptors based on the gene number of the respective chemokine ligand [55]. Thus, the receptor being bound and activated by SCYA1 coding for I-309 (now CCL1) became known as CCR1, and the receptor for $S C Y B 1$ coding for Gro- $\alpha$ became known as CXCR1.

Members of the hepta-helical group of receptors that bind chemokines, but do not associate with G-proteins (such as the duffy antigen receptor DARC) were excluded and later called atypical chemokine receptors (ACKRs) [56]. Currently, the human system comprises CCR1CCR10, CXCR1-CXCR6, CX3CR1, XCR1 and ACKR1-6 $(\mathrm{CXCR} 7=\mathrm{ACKR} 3)$. To unify the numerous synonymous names for chemokines, the nomenclature for chemokine receptors was adapted in 1998 to chemokines. For example, SCYA1 encodes chemokine CCL1 (I-309) and SCYB1 CXCL1 (Gro- $\alpha$ ). In humans, the CC-branch comprises CCL1-CCL28, the CXC-branch CXCL1-CXCL17, whereas CX3CL1 and XCL1-2 are the only members of the X3 and $\mathrm{C}$ families, in which the $\mathrm{N}$-terminal Cys residues are separated by three other residues or only a single $\mathrm{N}$-terminal cysteine exists (Table 1). In addition, some effector proteins like $\beta$-defensins, (macrophage) migration inhibitory factor (MIF) and high-mobility group protein 1 (HMGB1) share structural and functional features with chemokines and have been dubbed atypical chemokines or non-chemokine agonists as they bind to chemokine receptors (Table 1) [57, 58].

\section{Chemokine structures}

Chemokines have a characteristic tertiary structural fold known as the Greek key in which a dynamic N-terminal segment leads into a three-stranded $\beta$-sheet $(\beta 1, \beta 2, \beta 3)$, followed by a loop (the 50s loop) and a C-terminal $\alpha$-helix that folds onto the $\beta$-sheet (Fig. 2). The two highly conserved cysteines at the $\mathrm{N}$-terminus of any chemokine provide structural stability by forming disulfide bridges with two other strategically positioned cysteines, one within the $30 \mathrm{~s}$ loop that links to the first $\mathrm{N}$-terminal cysteine and a second cysteine between $\beta$-strands $\beta 1$ and $\beta 2$ that forms a disulfide bond with the sulfhydryl of the other N-terminal cysteine (Fig. 2).

Most chemokines can associate as homodimers (and in some instances to higher-order oligomers like CXCL4 (PF4) that forms tetramers) $[59,60]$. CXC and CC chemokines dimerize differently, yet in a conserved fashion. CC chemokines dimerize via interactions between $\mathrm{N}$-terminal sequences from two individual monomers, whereas CXC chemokines dimerize by anti-parallel $\beta$-sheet formation between the $\beta 1$-strands from two monomers, thus extending the 3 -stranded $\beta$-sheet in each monomer into a 6 -stranded 
Table 1 Human chemokines, their quaternary structures and main receptors

\begin{tabular}{|c|c|c|c|c|c|}
\hline Human chemokines & Systematic name & Conventional name(s) & Protein data bank ID* & Quaternary structures & $\begin{array}{l}\text { Main typical and atypical } \\
\text { chemokine receptors }\end{array}$ \\
\hline \multirow[t]{26}{*}{ CC family } & CCL1 & I-309; TCA3 & 1ELO, 4OIJ, 4OIK & $\mathrm{CC}$ dimer & CCR8, CCR11 \\
\hline & CCL2 & MCP-1; MCAF & $\begin{array}{l}\text { 1DOK, 1DOL, 1DOM, } \\
\text { 3IFD }\end{array}$ & $\begin{array}{l}\text { CC dimer, } \mathbf{C X C} \text { dimer/ } \\
\text { tetramer }\end{array}$ & CCR2, ACKR1, ACKR2 \\
\hline & CCL3 & MIP-1 $\alpha ;$ LD78 $\alpha$ & $\begin{array}{l}\text { 1B50, 2X69, 5COR, } \\
\text { 5D65 }\end{array}$ & $\mathrm{CC}$ dimer, polymer & CCR1,CCR5, ACKR2 \\
\hline & CCL3L1 & LD78 $\beta$ & NA & & CCR1, CCR5 \\
\hline & CCL4 & MIP-1 $\beta$ & 1HUM, 1JE4, 2X6L & $\mathrm{CC}$ dimer, polymer & CCR5, ACKR2 \\
\hline & CCL4L1 & LAG-1 & NA & & CCR5 \\
\hline & CCL5 & RANTES & $\begin{array}{l}\text { 1HRJ, 1RTN, 1U4L, } \\
\text { 2L9H, 5CMD, 5L2U, } \\
\text { 6AEZ, 6C6D, 6STK }\end{array}$ & $\begin{array}{l}\text { CC dimer, trimer, hex- } \\
\text { amer, 20-mer }\end{array}$ & $\begin{array}{l}\text { CCR1, CCR3, CCR4, } \\
\text { CCR5, ACKR1, ACKR2 }\end{array}$ \\
\hline & CCL7 & MCP-3 & $1 \mathrm{BO} 0,1 \mathrm{NCV}$ & $\begin{array}{l}\text { Monomer }>\text { CXC } \\
\text { dimer }\end{array}$ & $\begin{array}{c}\text { CCR1, CCR2, CCR3, } \\
\text { ACKR1, ACKR2 }\end{array}$ \\
\hline & CCL8 & MCP-2 & 1ESR & $\mathrm{CC}$ dimer & $\begin{array}{l}\text { CCR1, CCR2, CCR5, } \\
\text { CCR11, ACKR2 }\end{array}$ \\
\hline & CCL11 & Eotaxin & 1EOT, 2EOT, 2MPM & Monomer $>\mathrm{CC}$ dimer & CCR3, ACKR1, ACKR2 \\
\hline & CCL13 & MCP-4 & 2RA4 & $\mathrm{CC}$ dimer & $\begin{array}{l}\text { CCR1, CCR2, CCR3, } \\
\text { CCR11, ACKR1, } \\
\text { ACKR } 2\end{array}$ \\
\hline & CCL14 & $\mathrm{HCC}-1$ & 2Q8R, 2Q8T & $\mathrm{CC}$ dimer & CCR1, ACKR1, ACKR2 \\
\hline & CCL15 & HCC-2 & $2 \mathrm{HCC}$ & Monomer & CCR1, CCR3 \\
\hline & CCL16 & HCC-4; LEC & 5LTL & $\mathrm{CC}$ dimer & CCR1 \\
\hline & CCL17 & TARC & 1NR2, 1NR4, 5WK3 & $\mathrm{CC}$ dimer, tetramer & CCR4, ACKR1, ACKR2 \\
\hline & CCL18 & $\begin{array}{l}\text { PARC; DC-CK1; } \\
\text { MIP-4 }\end{array}$ & 4MHE & Monomer $>\mathrm{CC}$ dimer & CCR8 \\
\hline & CCL19 & MIP-3 $\beta ;$ ELC & 2MP1 & Monomer & CCR7, ACKR4, ACKR5 \\
\hline & CCL20 & MIP-3 $\alpha ;$ LARC & $\begin{array}{l}\text { 1M8A, 2HCI, } \\
\text { 2JYO,5UR7, 6WWZ }\end{array}$ & CXC dimer & CCR6 \\
\hline & CCL21 & 6Ckine; SLC & 2L4N, 5EKI & Monomer, hexamer & CCR7, ACKR4 \\
\hline & CCL22 & MDC; STCP-1 & NA & NA & CCR4, ACKR2 \\
\hline & CCL23 & CK $\beta 8 ;$ MPIF- 1 & $1 \mathrm{G} 91$ & Monomer & CCR1 \\
\hline & CCL24 & Eotaxin-2; MPIF-2 & $1 \mathrm{EIG}$ & Monomer & CCR3 \\
\hline & CCL25 & TECK & NA & NA & CCR9, ACKR4 \\
\hline & CCL26 & Eotaxin-3 & $1 \mathrm{G} 2 \mathrm{~S}, 1 \mathrm{G} 2 \mathrm{~T}$ & Monomer & CCR3 \\
\hline & CCL27 & CTACK; ILC; ESKINE & 2KUM & $\begin{array}{l}\text { Mixed CC and CXC } \\
\text { dimers, tetramer }\end{array}$ & CCR2, CCR3, CCR10 \\
\hline & CCL28 & MEC & $6 \mathrm{CWS}$ & Monomer & CCR3, CCR10 \\
\hline \multirow[t]{10}{*}{ CXC family } & CXCL1 & $\begin{array}{l}\text { GRO- } \alpha \text {; MGSA- } \alpha \text {; } \\
\text { MIP-2 }\end{array}$ & $1 \mathrm{MGS}$ & CXC dimer & CXCR2, CXCR1 \\
\hline & CXCL2 & $\begin{array}{l}\text { GRO- } \beta ; \text { MGSA- } \beta \text {; } \\
\quad \text { MIP- } 2 \alpha\end{array}$ & 1QNK & CXC dimer & CXCR2 \\
\hline & CXCL3 & $\begin{array}{l}\text { GRO- } \gamma, \text { MGSA- } \gamma \\
\text { MIP- } 2 \beta\end{array}$ & NA & & CXCR2 \\
\hline & CXCL4 & $\mathrm{PF} 4$ & 1RHP, 4R9W & CXC dimer, tetramer & CXCR3 \\
\hline & CXCL4L1 & PF4alt; CXCL4V1 & $4 \mathrm{HSV}$ & CXC dimer, tetramer & CXCR3 \\
\hline & CXCL5 & ENA-78 & 2MGS & CXC dimer & CXCR1, CXCR2, ACKR1 \\
\hline & CXCL6 & GCP-2 & NA & NA & CXCR1, CXCR2, ACKR1 \\
\hline & CXCL7 & $\begin{array}{l}\text { PPBP; CTAP-III; } \beta \text {-TG; } \\
\text { NAP-2 }\end{array}$ & 1F9P, 1NAP, 1TVX & CXC dimer, tetramer & CXCR2 \\
\hline & CXCL8 & IL8 & $\begin{array}{l}\text { 1IL8, 2IL8, 3IL8, } \\
\text { 6LFM }\end{array}$ & CXC dimer & CXCR1, CXCR2, ACKR1 \\
\hline & CXCL9 & MIG & NA & & CXCR3 \\
\hline
\end{tabular}


Table 1 (continued)

\begin{tabular}{|c|c|c|c|c|c|}
\hline Human chemokines & Systematic name & Conventional name(s) & Protein data bank ID* & Quaternary structures & $\begin{array}{l}\text { Main typical and atypical } \\
\text { chemokine receptors }\end{array}$ \\
\hline & CXCL10 & IP-10; CRG-2 & 1VL9, 1O7Y & CXC-type dimer & CXCR3 \\
\hline & CXCL11 & I-TAC, & 1RJT & Remains monomeric & CXCR3, ACKR3, ACKR1 \\
\hline & CXCL12 $\alpha, \beta, \gamma$ & SDF-1 $\alpha, \beta, \gamma$ & $\begin{array}{l}\text { 1QG7, 1SDF, 1VMC, } \\
\text { 2J7Z, 2KEC, 2SDF, } \\
\text { 3HP3 }\end{array}$ & $\begin{array}{l}\text { CXC-type and CC- } \\
\text { type dimers }\end{array}$ & CXCR4, ACKR3 \\
\hline & CXCL13 & BCA-1; BLC & 6VHJ, 7JNY & Atypical $\beta 0$ CXC-type & CXCR3, CXCR5 \\
\hline & CXCL14 & BRAK & $2 \mathrm{HDL}$ & NA & Unknown \\
\hline & CXCL16 & SR-PSOX & NA & & CXCR6 \\
\hline & CXCL17 & $\mathrm{DMC}, \mathrm{VCC} 1$ & NA & & Unknown, GPR35 \\
\hline \multirow[t]{2}{*}{ XC family } & XCL1 & $\begin{array}{l}\text { Lymphotactin; } \\
\text { SCM-1 } \alpha \text {; ATAC }\end{array}$ & 1J9O, 2JP1, 2NYZ & Alternative dimer & XCR1 \\
\hline & XCL2 & SCM-1 $\beta$ & NA & & XCR1 \\
\hline CX3C family & CX3CL1 & $\begin{array}{l}\text { Fractalkine; Neurotac- } \\
\text { tin; ABCD-3 }\end{array}$ & $1 \mathrm{~F} 2 \mathrm{~L} *$ & Unique, CC-like & CX3CR1 \\
\hline \multicolumn{6}{|c|}{ Atypical chemokines (ACK)* } \\
\hline & & MIF & $\begin{array}{l}\text { 1CA7, 1GCZ, 1GIF, } \\
1 \mathrm{MIF},\end{array}$ & $\begin{array}{l}\text { Monomer resembles } \\
\text { CXC-type dimer, } \\
\text { trimer barrel }\end{array}$ & CXCR2, CXCR4, ACKR3 \\
\hline & & hBD-1 & 1E4S, 1IJU, 2NLB & Monomer & CCR6 \\
\hline & & hBD-2 & 1FD3 & $\begin{array}{l}\text { Non chemokine like } \\
\text { dimers, octamer }\end{array}$ & CCR2 \\
\hline & & hBD-3 & $1 \mathrm{KJ} 6$ & Not well defined dimer & CXCR4, CCR6, CCR2 \\
\hline & & hBD-6 & 2LWL & Monomer & CCR2 \\
\hline
\end{tabular}

Quaternary structures of CC chemokines that can form CXC-type dimers and vice versa are highlighted bold. ACKR1 (DARC, Duffy Antigen Receptor), ACKR2 (D6). ACKR3 (CXCR7), ACKR4 (CCRL1), ACKR5 (CCRL2)

*PDB entries of wild-type chemokines were taken from rcsb.org if a corresponding publication was available

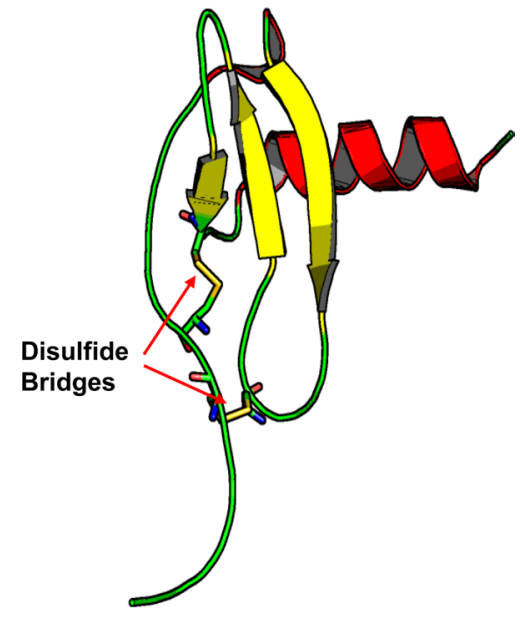

Fig. 2 Monomer structure of CXCL12 (PDB code: 4UAI). $\beta$-Strands are shown in yellow, and the C-terminal $\alpha$-helix is shown in red. The two cystine bridges are colored in green/yellow sticks, with red arrows indicating their positions

$\beta$-sheet, as well as by anti-parallel interactions of their helices with the surface of the $\beta$-sheet [61], as shown in Fig. 3 . There are some exceptions, however, namely CCL20 and
CCL7 that actually form CXC-type dimers, XCL1 that forms a $\beta$-sandwich-type structure [62, 63], CXCL12, CCL2 and CCL27 that can exist in both CC- and CXC-type conformations (Table 1) [64-66].

When examined in vitro in solution, chemokine homodimer dissociation constants normally fall in the $\mu \mathrm{M}$ range $[60,67,68]$. Some chemokines in solution exhibit larger $K_{D}$ values and thus exist primarily as monomers, as exemplified with CXCL7 [68] and LA-PF4 (low affinity PF4) [67]. Nevertheless, given their normally less than $\mu \mathrm{M}$ concentrations in plasma $[69,70]$, chemokines should be present as a distribution of monomers and homodimers in situ. Although under in vitro conditions chemokine oligomerization requires these relatively high concentrations, oligomerization has been shown to be relevant for leukocyte recruitment in vivo where much lower concentrations occur [71]. The explanation for this is that oligomerization depends on the chemical environment such as $\mathrm{pH}$, presence of ions and importantly on the presence of glycosaminoglycans (GAGs) $[72,73]$. The GAG contact region of the monomeric CC chemokines (CCL3, CCL4, CCL5) differs from that of their oligomer, because the oligomer conceals the $\mathrm{BBXB}$ recognition motif (B represents a basic residue) in the 40's loop, 
Fig. 3 CXCL4 and CCL5 homodimers (PDB codes: 1F9Q and $6 \mathrm{STK}$, respectively) are shown. Colors are displayed according to their secondary structures: $\beta$-strands in yellow, C-terminal a-helix in red, and loops in green. Cystine bridges are illustrated by yellow/green sticks

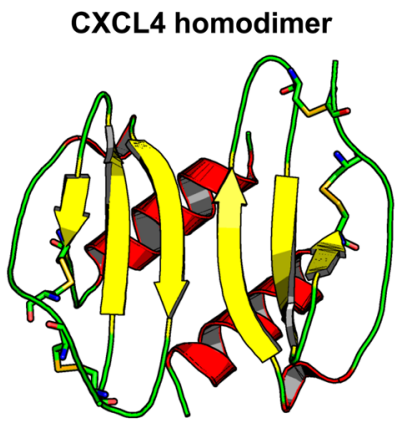

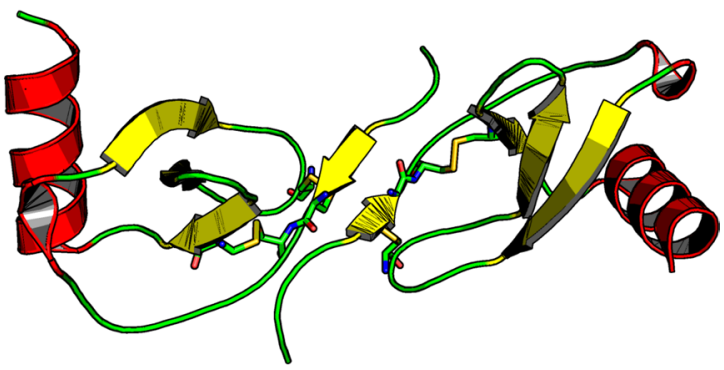

instead another cluster of basic residues in the 50's loop becomes the contact region, again illustrating the enormous complexity of the regulatory system [74]. Therefore, under steady-state conditions, chemokine dimerization is facilitated. Moreover, in inflamed tissues, local concentrations can be much greater, with their homodimeric state being significantly influenced by the overall cellular environment, e.g. local $\mathrm{pH}$, binding partners, ligands, and hydrophobic vs. hydrophilic interactions, as exemplified with CXCL4 (PF4) under various solution conditions [75]. Therefore, dissociation constants for chemokine dimerization measured in vitro are likely to be higher than those from a given chemokine in a physiological environment [69].

Chemokine oligomerization has implications for, e.g. cell migration and signaling, and is required for full activity in vivo [71] (for reviews, see also [76, 77]). As mentioned above, the chemical environment can strongly influence the extent of dimerization. Consider CXCL12 where negative ions (e.g. phosphate, sulfate), increasing $\mathrm{pH}$, addition of GAGs, as well as the presence of CXCR4-derived peptides, can promote its dimerization [72]. The ability of chemokines to oligomerize is considered an additional means of regulation of chemokine activity and, of note, gradient formation. This process is modulated by local microenvironmental factors. Both CC- and CXC chemokines can aggregate in solution and on cell surface-presented GAGs, with chemokinespecific differences being reported [76, 78]. Interestingly, the degree of sulfation and the positions of sulfate groups are key factors that regulate affinity, with this type of interaction being defined by some sort of sulfation code. How GAGs regulate chemokine function by affecting monomer/dimer levels, gradients, and importantly how GAGs may present chemokines to their receptors is a matter of ongoing research and been reviewed for ELR-chemokines binding to CXCR1 and/or CXCR2 [79].

To address the question as to whether chemokine homodimers or monomers bind to and activate their cell receptors, chemokines that normally form dimers have been engineered to prefer the monomeric state by mutating residues within the interfacial $\beta 1$ strand for CXC chemokines [80, 81] and within the interfacial $\mathrm{N}$-terminal sequence of $\mathrm{CC}$ chemokines [71, 82]. Using these monomer-engineered variants, it has been shown that monomers can retain full receptor-activating capacity, suggesting that chemokines can bind and activate their receptors as monomers. In contrast, covalent (also named locked or trapped) dimers of CXCL8 and CXCL12 have also been engineered, and show differential effects on signaling. Whereas the CXCL8 dimer is a potent CXCR2 agonist [81, 83], it has attenuated effects on CXCR1 and likewise the locked CXCL12 dimer has differential effects opposed to its constitutive monomeric variant, suggestive of biased agonism [84]. With Cryo-electron microscopy it has been possible to elucidate the structure of a CXCL8 binding as monomer or dimer to CXCR2 [85]. Here, CXCL8 chain A binds with its $\mathrm{N}$-terminus into the pocket and its core domain to the receptor $\mathrm{N}$-terminus whereas CXCL8 chain B resides mainly piggy-back on CXCL8 chain A weakly interacting with extracellular loop 2 of CXCR2 [85]. This supports the biological significance of distinct quaternary structures. Some chemokines can also associate into higher-order oligomers, as illustrated by formation of CCL5 di-, tri-, tetra- and hexamers (Fig. 4) and polymers of CCL3 [86], a structural issue that has physiological relevance. $[74,86]$

Although chemokines bind GAG chains with high affinity, the resulting biological consequences are diverse and may even present opposing effects. To explain this apparent diversity of experimental outcome, the versatility for structural heterogeneity of cellular GAGs should be noted, i.e. GAG chain length as well as degree and position of sulfation, because these factors affect chemokine binding [87]. The binding event also depends on whether the GAG is in solution (e.g. injected heparin) or bound to, and thus presented by, proteoglycan core proteins on cell surfaces. Providing the quintessential case for chemokine heparin binding, CXCL4 (PF4) binds the GAG at specific sites via interactions with a cassette of four lysines in its C-terminal $\alpha$-helix, and the loop containing Arg20, Arg22, His23 and Thr25 (as well as with Lys46 and Arg49), with the latter group actually being more crucial to GAG binding than lysines in the C-terminal helix [88]. With CXCL12, heparan sulfate interacts primarily with the homodimer interface, along with a cluster of basic 

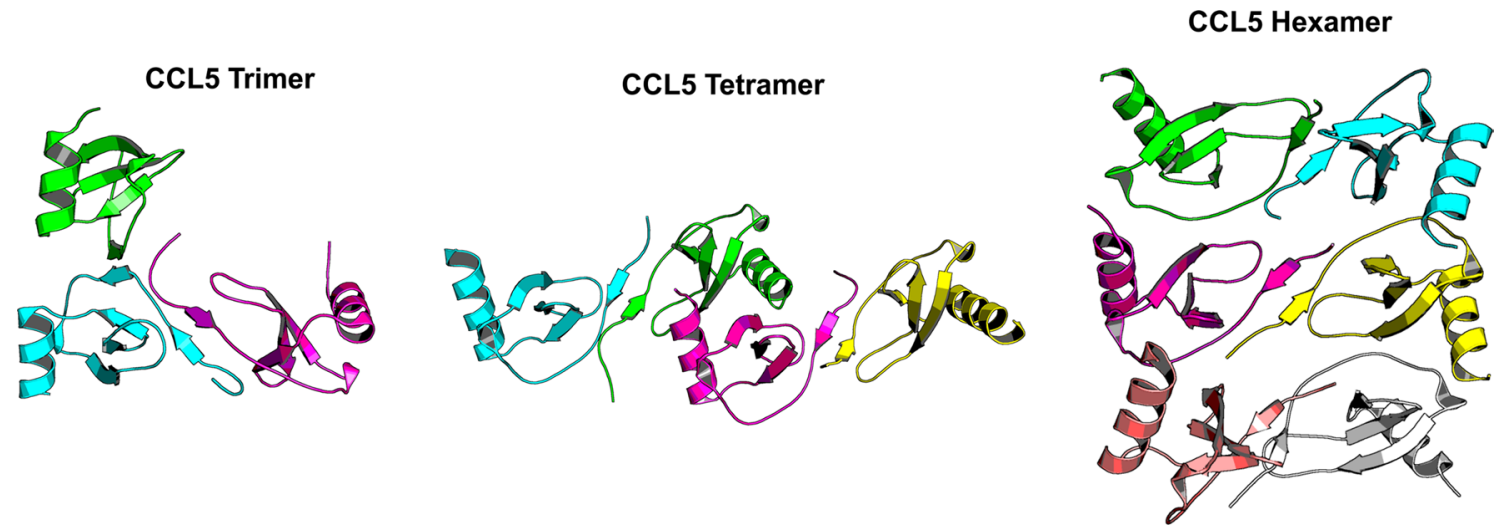

Fig. 4 CCL5 monomers can associate into various oligomeric states. The structures shown are for the trimer (PDB code: 6AEZ), CCL5 tetramer (PDB code: 2L9H), and CCL5 hexamer (PDB code: 5CMD)

amino acid on the exterior of the dimer [89]. GAG binding promotes formation of chemokine homodimers [71, 78, 90, 91], as well as affecting chemokine structure [90, 92]), structural dynamics [93], and chemokine dimerization [94]. In addition, heparin dodecasaccharide binding to CXCL4 induces higher-order oligomer formation that is dependent upon the chemokine GAG molar ratio, an effect that has implications for heparin-induced thrombocytopenia [95]. As a chemokine-binding partner, GAGs are pivotal to the broad spectrum of chemokine-mediated biological activities. In line with a crucial role for haptotaxis (i.e. chemotaxis along immobilized gradients), variants of CCL2, CCL4 and CCL5 that cannot bind GAGs cannot bind to the cell surface, and, although these three chemokines retain activity in vitro, they do not mediate leukocyte recruitment in vivo [71]. Further support for this concept stems from studies with the skin of mice where endogenous CCL21 gradients established on heparan sulfate have been visualized, these gradients enable directed migration of dendritic cells to lymphatic vessels [42] (Fig. 5).
Thus, while the importance of GAGs in chemokine recruitment and accumulation and gradient formation is well recognized, the role of GAGs in chemokine receptor activation is less well understood. There may be different mechanisms depending on the particular chemokine and its oligomeric state. If the sites where GAGs and receptors can bind to the chemokine overlap and interfere, ternary complex formation is impossible. For this case, the chemokine cloud model was presented by Graham et al. stating that "glycosaminoglycans provide an immobilized chemokine depot maintaining a 'cloud' of 'solution-phase' chemokines within the glycocalyx, and that it is this soluble form of any given chemokine that interacts with leukocyte-bound receptors" [96]. On the other hand, an alternative model for chemokines, specifically ELR-positive CXC chemokines such as CXCL8, was proposed by Rajarathnam et al., in which one chemokine binds to the GAG and the other to the receptor in a homodimer [79].
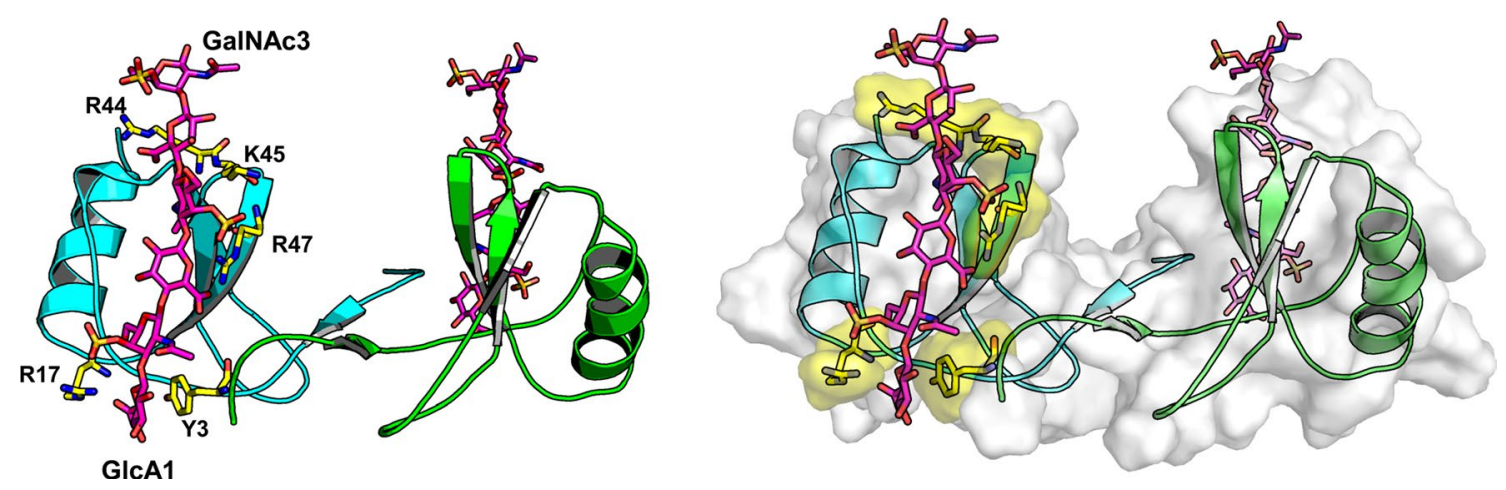

Fig. 5 A model of CCL5 in complex with a chondroitin sulfate hexasaccharide (magenta sticks) is shown [184]. GAG binding residues R17, R44, K45 and R47 are highlighted in yellow sticks 


\section{Chemokine-chemokine heterodimers}

Because the structure of all chemokine monomers is highly conserved, their ability to form homodimers is dictated primarily by residues at the inter-subunit dimer interface [97]. With this in mind, we hypothesized that monomers of different chemokines can exchange from one chemokine to another when the composition and spatial arrangement of residues at the heterodimer interface is energetically favorable vis-à-vis those in either chemokine homodimer [98]. For example, CXCL4, its N-terminal chimera PF4M2 [88] and CXCL8, as well as CXCL1 and CXCL7, readily swap subunits to form heterodimers with $K_{D}$ values similar to those of their respective homodimers [98-100].

Heterodimers of CXC and CC chemokines (e.g. CXCL4 and CCL5) also form in cultured cells, as well as in vivo [101, 102]. CC chemokines CCL3/4 and CCL2/8 (macrophage inflammatory protein-1 $\alpha$ (MIP- $1 \alpha)$ and $-1 \beta$ (MIP-1 $\beta$ ), respectively, Table 1) can also form heterodimers in vitro, as well as being secreted as heterodimers from activated monocytes and blood lymphocytes [103]. The detectability of chemokine heterodimers under these conditions where chemokine concentrations are lower than those, e.g. in NMR studies, indicates that a physiological, cellular environment can facilitate homo- and heterodimerization. Indeed, the presence of GAGs increases chemokine heteromerization in such a way that in some instances, e.g. CCL2-CCL11 and CCL8-CCL11, the heterodimer is preferred over the homodimer [94]. As with chemokine homodimers, their heterodimers are also structurally stabilized by GAG binding [104, 105].The GAG contact sites in (hetero)oligomers can be different from those in the monomer. One example is CCL5 that interacts with its BBXB motif in the 40's loop that becomes buried upon oligomerization and is exchanged by a motif of basic residues in the 50's loop. This CCL5-CXL4 heterodimer can explain some functional effects, because they are protected from proteolytic degradation [74, 104]. Many questions (especially when it comes to multiple coexisting chemokines) remain open. For example, could it be that several chemokine gradients exist simultaneously or that multiple chemokines can assemble into higher-order structures? Moreover, it has been postulated that chemokine activity may be regulated through GAGs, independent of chemokine receptor binding [74].

There is compelling evidence that chemokine homoand heterodimers can exert biological activity through chemokine receptors even if this activity is biased and deviates from the monomeric form. This was demonstrated using obligate (constitutive) forms that are covalently and specifically linked to mimic their natural counterparts. This has been shown for homodimers of CXCL1 [83],
CXCL8 [81], and CXCL12 [84], as well as heterodimers CXCL7-CXCL1 [106] and CC-type CCL5-CXCL4, CCL5CCL17 [102]. Their activity range expressed as EC50 values fall in the nanomolar range $(5-15 \mathrm{nM})$. GAGs bind to a heterodimer in a way where one partner binds and supposedly recruits the chemokine to a GAG, whereas the other partner activates the receptor as shown for the heterodimer CXCL4-CCL5 with CCL5 being the active part [102]. An alternate explanation has been presented by Liang et al. who explain the activity of CCL5-CXCL4 heteromers with a model that shows the assembly of CCL5-CXCL4 heterodimers into higher-order heterooligomers with increased affinity for the GAG [74]. Another mechanism happens on cells where chemokine heterodimers meet heteromers of their receptors as shown for CCL5-CCL17 and CCR5CCR4 on T cells [102].

Nesmelova et al. used molecular dynamics (MD) and mechanics simulations to calculate free energies for heterodimerization of several CXC and CC chemokines and reported that a number of $\mathrm{CXC}$ and $\mathrm{CC}$ chemokine pairs (within and between CXC and CC families) may associate as heterodimers in solution [97]. For example, CXCL4 forms CXC-type heterodimers with CXCL1, CXCL7, and CXCL8, as well as CXCL1/L8, CXCL7/L8 and CXCL1/ L7. In addition, CCL2 can form CC-type heterodimers with CCL5 and CCL8, as well as CXC-type heterodimers with CCL8 [13, 97]. It seems plausible that when chemokines dimerize within an interaction type $(\mathrm{CC}, \mathrm{CXC})$ and exchange monomers, the interaction type is retained. However, there are cases, e.g. when chemokines of different types are combined, where it is more difficult to predict which heterodimer type (CXC or CC) will prevail. Typical examples are CCL5, which forms a CC-type heterodimer with CXCL4. Some mixed chemokine combinations, such as CCL2 and CXCL8, can give rise to both CC and CXC types. Surprisingly, there also seem to be heterodimers of two different CC chemokines, such as CCL2 and CCL8, which can form both CC- and CXC-type heterodimers [97]. Modeled CXCtype and CC-type heterodimer structures are shown in Fig. 6 for the CXCL4/CCL5 pair, with the CC-type heterodimer being more energetically favored, an observation that has been empirically validated in vitro and in vivo [102].

\section{Chemokine receptors}

In most cases, chemokine signaling is mediated by conventional chemokine receptors. This is not the case when a chemokine has no high-affinity receptor as with CXCL4 that has an indirect effect on chemokine cell receptors. Instead of direct binding to a cognate chemokine receptor, CXCL4 primarily may exert its biologic activity by binding to and modulating the activity of other soluble 


\section{CCL5-CXCL4 Complex (CXC-Type dimer)}

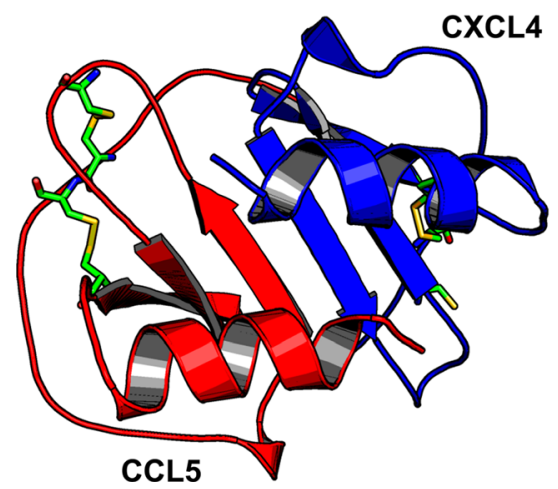

CCL5-CXCL4 Complex

(CC-Type dimer)

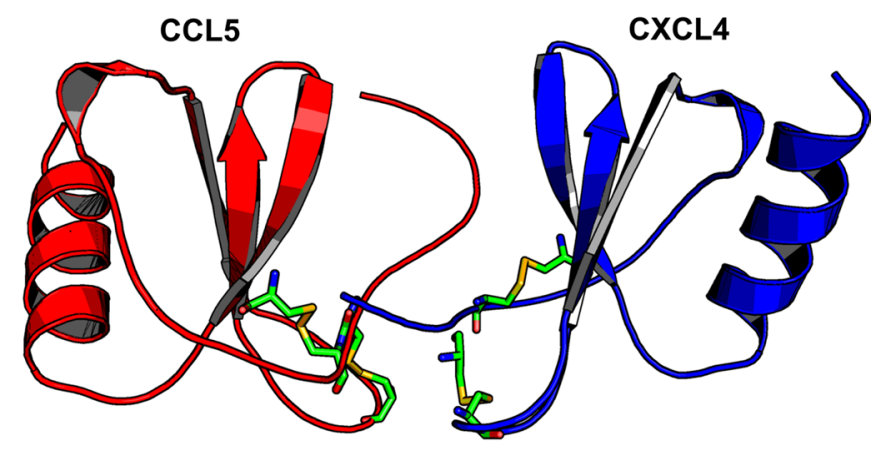

Fig. 6 Models of the CXCL4/CCL5 heterodimer are shown. These structures are based on NMR spectroscopical HSQC chemical shift and intensity changes measured in a mixture of ${ }^{15} \mathrm{~N}$-labeled CXCL4 and ${ }^{15} \mathrm{~N}$-labeled CCL5. NMR data directed manual docking and energy minimization using MD simulations [102]. This in silico study

mediators, including growth factors (FGF-2, VEGF) and chemokines as we will discuss in a later section [99, 107-110]. Due to a lack of stability, it has been impossible to delineate the three-dimensional structure of a wild-type chemokine receptor in complex with a soluble wild-type agonist chemokine by crystallography or NMR spectroscopy. However, in combination with ortho- and allosteric small molecule antagonists or using engineered variants that produce stable complexes, it has been possible to obtain structures of the G-Protein coupled receptors CXCR4, CCR2, CCR5 and CCR6 [111-114]. Only recently has cryo-EM made it possible to resolve the structure of a chemokine (CXCL8) in association with its receptor CXCR2 [85].

Most investigators assume a two- or three-step receptoractivation model in which the chemokine initiates the first binding step with the $\mathrm{N}$-terminal domain of the receptor (site I) interacting with the dynamic $\mathrm{N}$-terminus and $\mathrm{N}$-loop [115]. Known structures of the receptor $\mathrm{N}$-domain with the chemokine similarly show that the residues proximal to the second cysteine of the $\mathrm{N}$-domain are involved [116]. Due to their low sequence homology, it is likely that it is the $\mathrm{N}$-domains that confer binding specificity. The $\mathrm{N}$-domain of CXCR1 and CXCR2 have been reported to reach out to and catch CXCL8 which happens with moderate affinity. This induces a subsequent stabilization of the receptor $\mathrm{N}$-domain $[85,116]$ and leads to a subsequent movement of CXCL8 until a position on the receptor and a high-affinity conformation is reached where the chemokine interacts with site II so that the residues that mediate the contact change during the binding process. This conformation allows CXCL8 to bind to CXCR2 in both the monomeric and dimeric forms, as the dimer interface is not affected [85]. was performed using CXCL4 and CCL5 monomers initially docked as a CXC-type dimer or a CC-type dimer as indicated. The CC-type heterodimer was highly energetically favored. CCL5 monomers are in red, CXCL4 monomers are in blue, and cystine bridges are colored in green/yellow sticks

While the contact region of the $\mathrm{N}$-domain is similar for the receptor structures we know, the corresponding contact region of the chemokines varies. For instance the N-domain of CCR5 binds to two regions, the N-loop and the BBXB motif in the 40s loop of CCL5 that is important for GAG binding whereas the $\mathrm{N}$-domain of CXCR4 interacts with the $\beta 1$-strand of CXCL12 [117]. CXCL12 has been engineered to be in either a constitutive monomeric or dimeric form and both forms bind differently to the CXCR4 N-domain with the monomer interacting with the residues of the most distal residues and the dimer preferring the proximal residues [118]. Whether ternary complexes of receptors and chemokine (hetero)dimers can possibly form depends on whether the contact regions on the chemokine for GAG, receptor and dimerization compete which needs to be investigated for each case in the future.

Superposition of these structures shows that the N-terminus of the chemokine ligand 'dips' into the receptor. However, major differences exist in the precise mode of binding or how deeply the chemokine dips into the binding pocket [112].

GPCRs adopt distinct conformations that are in dynamic equilibrium [119], and binding of a chemokine agonist to the extracellular portion of the receptor shifts that equilibrium to an activated state [119]. Chemokine receptors bind to several members of the Goi-family $\left(\mathrm{G \alpha i}_{1}, \mathrm{G \alpha i}_{2}, \mathrm{G \alpha i}_{3}, \mathrm{G \alpha o}_{\mathrm{a}}, \mathrm{G \alpha o}_{\mathrm{b}}\right)$, as well as to $\mathrm{G} \alpha 12$ [120], and several chemokine agonists of CCR2, CCR5 and CCR7 are activated with varying potency that is independent of their affinity for G-proteins, indicating that signaling bias occurs also at this level [120].

This ligand-receptor interaction leads to conformational changes within the Go state and results in exchange of GDP with GTP (Fig. 7). The heterotrimeric G protein detaches 


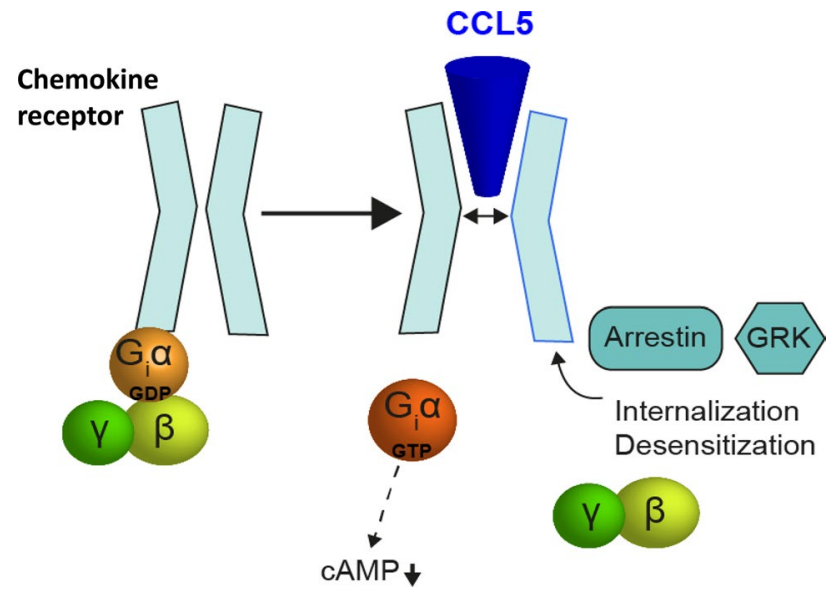

Fig. 7 Chemokines bind to receptors, whose cytoplasmic region is an adaptor for G-proteins and can transmit signals via arrestins after their docking following phosphorylation by $\mathrm{G}$ protein-coupled receptor kinase (GRK)

from the receptor, and the $\beta \gamma$ - and $\alpha$ i-units separate, thus initiating signaling cascades [119] (Fig. 7). Goi inhibits adenylate cyclase, and intracellular levels of the second messenger cAMP drop with ensuing effects on the activity of cAMP-dependent protein kinases (PKs). The exact mechanisms as to how Goi signals induce cytoskeleton rearrangement that drives cell movement are unknown. Distinct signaling pathways and biased signaling are important ways to explain why different ligands (binding as homo- or hetero-dimers to the same GPCR) can have different and even opposing functional effects [121].

Chemokines can also interact and signal via their GPCRs in conjunction with $\beta$-arrestins and $\mathrm{G}$ protein receptor kinases (GRKs) (Fig. 7). Upon chemokine ligand binding, GPCR cytoplasmic residues become phosphorylated by GRKs, e.g. upon CXCL12 stimulation [122]. Importantly, this type of site-specific phosphorylation of CXCR4 results in both positive and negative modulation of CXCR4-mediated signaling [122]. Phosphorylation at the $\mathrm{C}$-terminus of CXCR4 is structurally distant from the $\beta$-arrestin-binding site, yet it is prerequisite for association of $\beta$-arrestins with CXCR4 and its internalization. Differences in ligand-binding modes can lead to differences in receptor signaling, a process termed "biased signaling" as reported for the $\beta 2$-adrenergic receptor $[123,124]$. Because the intricacies of signaling can be regulated in a ligand-biased manner, a change in the binding mode, e.g. between CXCL12 and CXCR4 (perhaps caused by heteromerization) can shift or uncouple pathways that lead to chemotaxis, CXCR4 internalization, and CXCR4 desensitization.

To add another layer of complexity, chemokine receptors themselves can oligomerize. Normally, chemokine receptors exist constitutively as dimers, like CXCR4, and/or associate as oligomeric heteromers. By modifying their conformations, chemokines can activate receptors to which they do not primarily bind [125]. E.g. CCR2 forms heterocomplexes with CCR5, and oligomeric complexes of CCR2, CCR5 and CXCR4 also exist [126, 127]. Hetero-oligomerization of chemokine receptors can be induced by binding chemokine heterodimers with functional and therapeutic consequences. Negative and positive cooperative effects can also occur, and the use of specific chemokine inhibitors can result in allosteric trans-inhibition [102, 128, 129]. Obviously, the possibility for heterodimer formation facilitates a spatial bridging between different receptors, an activity underlying galectin-mediated lattice formation on the cell surface.

With an eye on molecular interactions among chemokine family members in both homo- and heterodimer states, the scope of similar interactions beyond this family can be extended to tissue lectins with galectins as in situ candidates. This concept warrants a further look into this family of lectins.

\section{Galectins}

Aggregation of erythrocytes (haemagglutination) induced by serum antibodies has revealed the presence of distinct surface epitopes that are the molecular basis of blood groups [130]. Respective typing of red blood cells was also achieved by another type of reagent with an antibody-like level of specificity, i.e. (glyco)proteins in plant extracts termed lectins (from Latin lectus, the past principle of legere meaning to read, choose or select [131-134]. Sugar-mediated inhibition of lectin-dependent haemagglutination was not only instrumental for identifying carbohydrates as the building blocks for blood group epitopes [135], but established a robust and popular experimental set-up to detect lectin activity.

Because "complex carbohydrate-containing molecules may function in synaptic recognition and transmission through establishment of cell-cell contacts and possibly also as mediators of communication between the surface and the interior of the cell, the presence in neural tissue of enzymes and proteins capable of interacting with saccharides is to be expected" [136]. The testing of extracts from the electric organ of Electrophorus electricus (and also chicken, mouse and rat organs and cells) and inhibition of galectin-dependent erythrocyte clumping by $\beta$-galactosides (most potently by thiodigalactoside) led to the purification of the first galectin [136]. In this case, the presence of a reducing agent, i.e. dithiothreitol, is essential to preserve activity, leading to coining the first name for such lectins, i.e. S-type lectins. "The finding that S-type lectins form an evolutionarily related family, with certain residues being critically conserved" [137] prompted the search for additional 
homologous proteins by computer-assisted sequence alignment, and then to progressively track all members of this family at the genome level [138]. In this way, galectins can be viewed in situ as a network of such mediators $[139,140]$.

\section{Galectin structures}

The common structural feature of galectins is their $\beta$-sandwich-type (jelly roll-like) fold of the carbohydrate recognition domain (CRD) as shown in Fig. 8. Intrafamily sequence differences among galectins around their $\beta$-galactoside binding site defined by a central, highly conserved tryptophan (for $\mathrm{C}-\mathrm{H} / \pi$-interactions with the $\mathrm{B}$-face of galactose) can generally explain differences in ligandbinding affinities [141-143]). Another aspect of functional importance for vertebrate galectins is their quaternary structure in which the CRD can be presented in three types of modular architectures [144, 145]: proto-type (non-covalently associated homodimers, like chemokines), tandemrepeat type (covalently linked heterodimers) and chimera type (natural fusion protein of a CRD with an $\mathrm{N}$-terminal tail for self-association and for post-translational modification by serine phosphorylation). Figure 8 shows the crystal structures of two proto-type galectins (Gal-1 and Gal-7), and the only chimera-type galectin, Gal-3, in which the CRD is devoid of its $\mathrm{N}$-terminal tail has been crystalized. The two $\beta$-sheet faces of the conserved CRD $\beta$-sandwich structure (sugar-binding S-face, and opposing F-face) are shown for the Gal-3 CRD in Fig. 8, an illustration that underscores the CRD structural bivalency with these two faces.

Even though galectins are known primarily for their recognition of and binding to $\beta$-galactosides, they can also interact with other types of glycans at their S-face, e.g. Gal-1 binding to $\alpha$-linked digalactosides [146] and $\alpha$-galactomannans [147]. In fact, the sugar-binding domain on the CRD S-face is more extensive for a complex glycan than for simple saccharides which has implications for galectin-glycan interactions at the cell surface [148]. Moreover, Gal- 1 and Gal- 3 can bind $\alpha$-galactomannans at an alternative sugar-binding domain on the CRD F-face [147, 149]. These findings greatly broaden the glycospace available to galectins and complicate elucidation of the "sugar code" [137].

The modular arrangement of a given galectin determines the topological properties of galectin-glycoconjugate complexes. This is a salient feature in terms of initiating (or not) cell signaling as inferred from precipitation experiments and negatively stained electron micrographs with glycoclusters and Gal-1 or Gal-3; with Gal-3, rather heterogeneous and disorganized complexes are observed in contrast to wellordered homogenous Gal-1-glycoconjugate complexes [150]. In cell growth regulation, wild-type galectins with different architectures, i.e. Gal-1 and -3 , can thereby be antagonistic [151], and engineered variants with a switch in modular design (i.e. from prototype to chimera type or vice versa for Gal-1 and -3) exhibit different binding profiles in tissues and architecture-dependent responses by inhibiting proliferation or acting as antagonists [25, 152]. These results reveal the functional significance of modular architectures.

\section{Galectin function}

Physiologically, galectin-glycan binding facilitates a broad range of activities, such as intracellular routing, delivery of glycoproteins, and bridging of counter-receptors on
Fig. 8 Homodimers of different galectins (Gal-1, PDB code: 1GZW; Gal-3, PDB code 3AYE: Gal-7, PDB code 5H9S). Colors are shown according to their secondary structures $(\beta$-strands in yellow, $\mathrm{C}$-terminal $\alpha$-helix in red, and loops in green), and bound lactose is drawn by magenta sticks. The two $\beta$-sheet faces of the CRD $\beta$-sandwich (sugar-binding $\mathrm{S}$-face, and opposing $\mathrm{F}$-face with contact site for CXCL12) are indicated with the Gal-3 structure
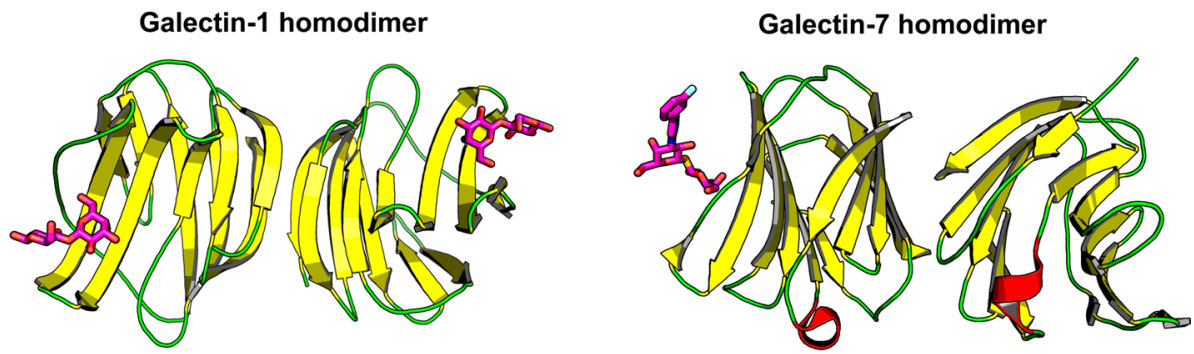

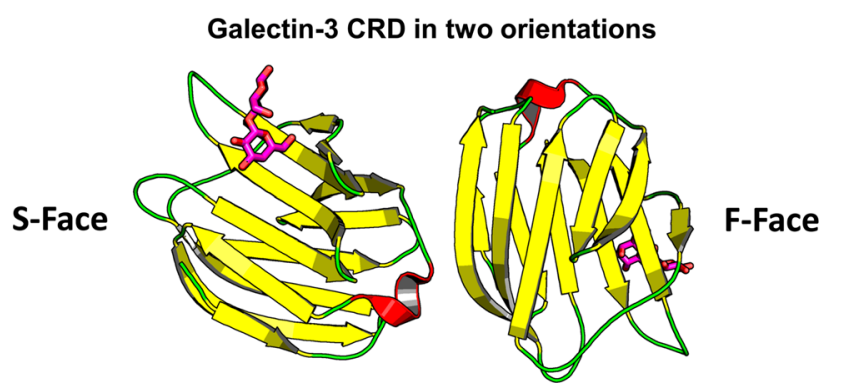


the cell surface (in cis and trans). It is noteworthy that each of these processes is highly specific and attributed to pairing with cell type-dependent counter-receptors $[153,154]$. Even a small sugar headgroup, such as that presented by sulfatide, can establish the contact site which makes 'reading' possible [155]. For example, long chains of $\mathrm{N}$-acetyllactosamine (polyLacNAc) have high ligand capacity for distinct galectins [156], and for the Gal-3 CRD even allows for clustering with the possibility for stable contacts [157]. With the inflammatory cascade, Gal-8, e.g. can bind glycans of the $\beta_{2}$-integrin lymphocyte function-associated antigen-1 (LFA-1), an event that allows the lectin to interfere with the integrin's interaction with intercellular adhesion molecule-1 (ICAM-1) [158]. Although high-resolution structures of a cell receptorbound galectin are unknown, NMR spectroscopy has been used for insight into the binding of Gal-3 to endothelial cell adhesion molecule (ECAM) CD146 [159].

When functioning intracellularly as sensors for membrane damage, galectins have an intriguing role beyond just glycan binding. For example, Gal-3 and Gal-8 can track membrane rupture that makes complex-type $\mathrm{N}$-glycans accessible via their lectin activity ('sensing danger') [27, 28]. Galectins can also 'call for help' and organize joint efforts by building molecular bridges from the "danger signal" to components of autophagy or lysosome repair machineries, such as the $52 \mathrm{kDa}$ nuclear dot protein (NDP52) [160] or tripartite motif (TRIM) proteins like TRIM16 [161-163]. With Gal-8 and NDP52, this bridging has been elucidated by crystallographic studies that led to the discovery that hydrophobic interactions and numerous hydrogen bonds between the F-face of the C-terminal CRD of Gal-8 and NDP52 convey specificity to this protein-protein interaction [164, 165]. The canonical glycan-binding site (on the S-face of galectin CRDs) remains open for contact in both CRDs of the tandem-repeat-type Gal-8.

Because galectins have no signal peptide and thus do not enter the ER-Golgi-based export route [166, 167], their cytoplasmic presence predestines them for a role in intracellular surveillance. The case of Gal-8 interacting with an autophagy adaptor (as well as evidence for heterodimer formation among galectins discussed above) on the structural level is the realization of the attractive possibility of hetero-bivalency that enables simultaneous protein-glycan and protein-protein interactions. Following their non-classical secretion from cells (e.g. with Gal-3 in inflammation), galectins will then be exposed to chemokines within the extracellular space, as well as to their receptors and chemokine-receptor complexes on the cell surface in inflamed tissue. Relevant information for the obvious type of binding, i.e. the glycan-dependent interaction, in this setting has been reported, yet so far only in a single instance, i.e. a cytokine and a receptor [168].
On the receptor level, the extent of cellular response to interferon- $\gamma$ (IFN $\gamma$ ) is sensitive to the frequency of N-glycosylation of the receptor R2 subunit. This effect is linked to Gal-1 and Gal-3 lattice formation that is modulated by acquisition of a new sequon for $\mathrm{N}$-glycosylation by a Thr168 to Asn mutation. In this regard, it shifts the glycoform with an additional $\mathrm{N}$-glycan from sphingolipid/cholesterol to those associated to the actin cytoskeleton, such that the intracellular changes upon ligand binding that activate the JAK/STAT signaling cannot occur [169]. Intriguingly, this $\mathrm{N}$-glycosylated cytokine itself (and also interleukin-12 but not the O-glycosylated chemokine CCL6 and the N-glycosylated CCL1) is a ligand for Gal-3 via glycan binding so that retention of IFN $\gamma$ in the tumor's extracellular matrix is made possible by Gal-3 residing there [168]. As conclusion, the glycan-binding S-face of a galectin is active in this aspect of immune activity. Inspired by the ability of chemokines to form heterodimers, we tested the hypothesis that galectin CRDs can also associate as heterodimers via protein-protein interactions.

\section{Galectin-galectin heterodimers}

As with chemokines, galectins can indeed form non-covalently associated heterodimers (hybrids) [170]. In this way, the Gal-3 CRD acquires a new level of functionality as a bivalent hybrid where interactions at the heterodimer interface (e.g. those between Gal-3 and Gal-7 CRDs) have been characterized by NMR spectroscopy and molecular modeling (Fig. 9). Intriguingly, cis/trans-isomerization of the

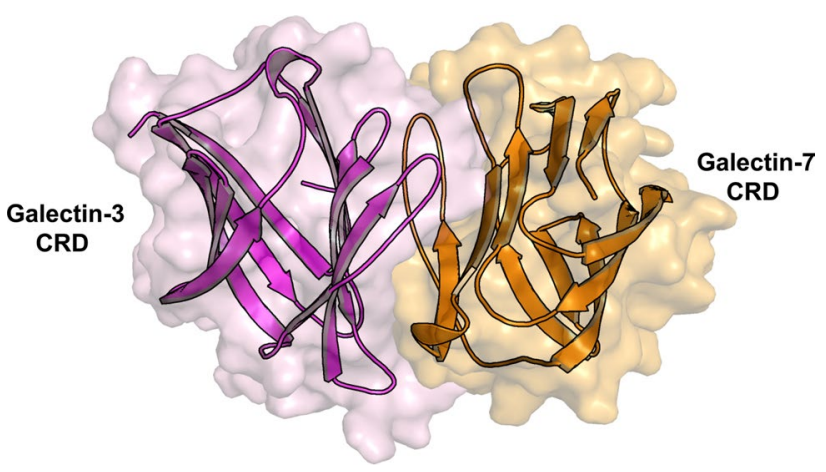

Fig. 9 A model is shown for the heterodimer formed between a Gal-3 CRD (magenta ribbon and surface, PDB code: 1AUK) and a Gal-7 CRD (orange ribbon and surface, PDB code: $4 \mathrm{GAL}$ ). This structural model of the Gal-3/Gal-7 heterodimer was derived by protein-protein docking using NMR data to pinpoint "hot spots" for key interacting residues at the interface, this to guide complex formation [170]. Multiple docking poses were subjected to MD simulations and binding free energy (BFE) calculations. The docking pose represented here exhibited the lowest BFE value, thus indicating the thermodynamically most favorable conformation, which was selected as the most likely structure of the heterodimer 
Pro4 peptide bond in Gal-7 appears to be a molecular switch for the Gal-7 homodimer to dissociate at low concentration, making the Gal-7 CRD available to generate such a hybrid [171]. Cell-binding studies have underscored the possibility of bioactive heterodimers of the Gal-3 CRD with Gal-7 and also Gal-1 CRDs [170]. Environmental conditions can dictate the extent of heterodimerization that extends the bioactivity range of galectins, opening a promising way to look for new, so far unsuspected CRD permutations within the galectin family. Having documented the galectin CRD F-face as a platform for protein-protein contacts, the concept of interplay with a chemokine is not unrealistic.

\section{Chemokine-galectin heterodimers: example of CXCL12-Gal-3}

Collectively, structural data on chemokine-chemokine and galectin-galectin heterodimers provided the incentive to examine the fundamental hypothesis that galectins and chemokines interact to form heterodimers. As outlined below, our first step in this regard was to establish an "interactome" of chemokines that associate with Gal-1 and Gal-3. With NMR resonance assignments and structural characterizations in hand for both galectins $[172,173]$ and for the chemokine CXCL12 [174, 175], the proof-of-principle was solidly established up to the level of mapping contact sites [176]. This in turn opened the way to explore the potential for this type of interaction and to elicit functional effects in vitro and in vivo, with the perspective of a full-scale network analysis.

As noted above, Gal-1 and -3, like some chemokines, are upregulated during inflammation and are among the most abundant and best studied galectins in inflammatory diseases. Under inflammatory conditions, metalloproteinases cleave the $\mathrm{N}$-terminal region of Gal-3, resulting in free Gal-3 CRD [177-179]. Therefore, the encounter of these galectins with chemokines becomes highly likely and directs our interest to demonstrate heterodimerization by direct interactions in vitro. Solid-phase and surface plasmon resonance-based assays showed that Gal-1 and Gal-3 (as well as the Gal-3 CRD) bind to specific chemokines from CC-, CXC-, XC- and CX3C-families [176]. The $\mathrm{K}_{\mathrm{D}}$ values for CXCL12 binding to Gal-3 and Gal-3 CRD by surface plasmon resonance are $80 \mathrm{nM}$ and $34 \mathrm{nM}$, respectively. The chemokine-binding patterns to these galectins demonstrate remarkable selectivity, and, as evidenced by NMR HSQC data analysis, the binding epitope on either galectin does not involve the canonical sugar-binding site on the CRD S-face [176]. Knowledge of the binding epitopes on both the galectin and paired chemokine has allowed us to model the galectin-chemokine heterodimer, a model that was validated by mutagenesis studies [176].
The largest contiguous Gal-3 CRD contact region with CXCL1 12 comprises $\beta$-strands $\beta 8-\beta 9$ within the Gal-3 CRD F-face that opposes the canonical sugar-binding S-face of the CRD $\beta$-sandwich (Fig. 10). CXCL12 binding to Gal-3 allosterically affects residues within the sugar-binding site, like N160 that is not in direct contact with the CXCL12binding site on the F-face. This finding has implications for Gal-3's activity as a lectin, in that Gal-3 in principle can still bind $\beta$-galactosides even when CXCL12 is bound. From the perspective of the chemokine, CXCL12's $\beta 1$-strand is an important contact site for binding to GAGs, and CXCL12's binding to heparin attenuates heterodimerization of CXCL12 and Gal-3, an observation that has implications for GAGregulated biology of CXCL12. In principle, a chemokine dimer can be presented by a GAG and simultaneously to its receptor (Fig. 11) [79]. For the Gal-3-CXCL12 heterodimer, a prerequisite would be that Gal-3 binds to GAGs, and indeed it does $[156,180]$. This requires that the dimer interface does not overlap with the GAG/receptor binding site. Our model is based on chemical shifts of CXCL12 when Gal-3 is binding and the affected residues are similar to those of the CXCL12 homodimer indicating an overlap with the receptor binding site and the GAG binding site. Therefore, we believe that a complex of GAG, CXCR4, CXCL12 and Gal-3 cannot exist at the same time. Nevertheless, proteoglycans can play an important role by changing the equilibrium of the individual interactions in which the components come together in close proximity, so that the diffusion distances are short.

Gal-3 (a.k.a. macrophage marker Mac-2 [181]) is expressed by tumor-associated macrophages that are responsible for reducing the mobility of other leukocyte subsets, especially CD8+ T cells [182]. In this respect, the binding of Gal-3 to IFN $\gamma$ and to chemokines may be mechanistically relevant $[168,176]$. Indirectly, Gal-3 inhibits chemokinedependent migration of CXCR3-expressing lymphocytes by preventing diffusion of IFN $\gamma$ and in turn the upregulation of chemokines CXCL9, CXCL10, and CXCL11. Recently, evidence for direct biological effects from Gal-3-chemokine heterodimers has been reported with the inhibition of CXCL12- or CCL26-mediated chemotaxis (CXCL12induced T-cell and neutrophil migration and CCL26-induced eosinophil migration) being attenuated by heterodimer formation with full-length Gal-3 or its CRD [176].

With galectin binding to a mediator via a glycan (IFN $\gamma$ ) or protein (CXCL12), inhibition is likely the result of reduced receptor signaling. In the case of IFN $\gamma$, it has been proposed that Gal-3 acts as a scavenger for the cytokine [168]. In the case of Gal-3 interacting with CXCL12, heterodimer Gal-3/CXCL12 complexes have been detected on the cell surface, and modeling of the Gal-3/CXCL12 heterodimer bound to CXCR4 shows that bound Gal-3 occurs without steric hindrance of CXCL12 binding to CXCR4 (Fig. 12). 
(A) CXCL12 homodimer

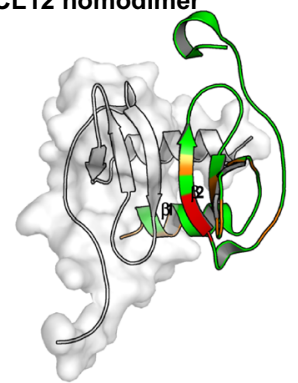

(C) CXCL12-Gal-3 CRD heterodimer

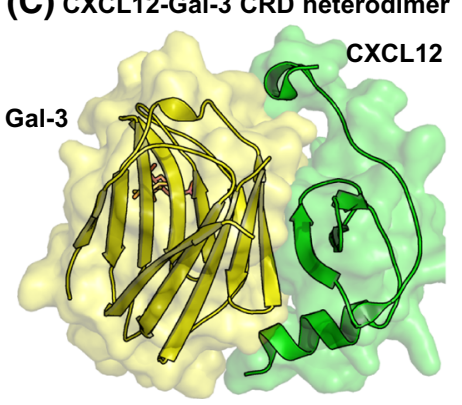

(B) Gal-3 CRD in two orientations

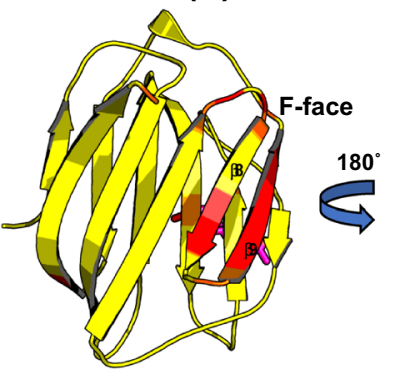

(D) HSQC spectral expansions

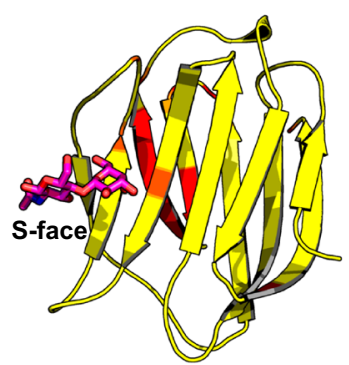

(E) highlighted model

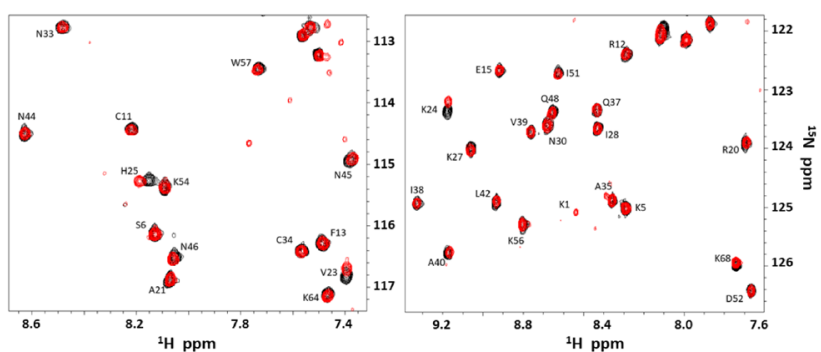

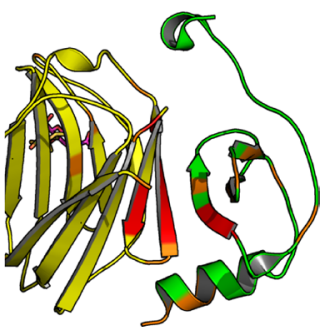

Fig. 10 Heterodimer by CXCL12-Gal-3 CRD association. (A) The crystal structure of the CXCL12 homodimer (PDB code: 4UAI) is shown with monomer subunits highlighted in green and red. (B) The structure of the Gal-3 CRD (in yellow and red) bound with lactose (in magenta) (PDB code: 1A3K) is shown. (C) A model of the heterodimer formed between CXCL12 (green) and Gal-3 (yellow) derived from NMR-directed protein-protein docking, MD simulations and
BFE calculations is shown [176]. (D) Spectral expansions of HSQC data of ${ }^{15} \mathrm{~N}$-labelled CXCL12 in the absence (black contours) or presence (red contours) of the unlabelled Gal-3 CRD are shown. (E) The NMR-based heterodimer model is shown with residues that are most perturbed by interactions between Gal-3 and CXCL12 highlighted in red and orange

group. This approach, in turn, can miss physiologically important possibilities for "teamwork" among protein effectors from different classes by specific associations (i.e. hybrid formation) when they occur within the same micro-environment. Relatedly, the following points favor broadening investigations into our heterodimer discoveries: (i) concentrations of some chemokines and galectins are elevated at sites of inflammation, (ii) chemokines and galectins can interact with each other within their family in diverse manners, including heterodimer formation, and (iii) galectins can engage in glycan and protein recognition with chemokines. The CXCL12-Gal-3 interaction studied on the structural level by NMR spectroscopy and molecular modeling provides a proof-of-concept for specific pairing of galectins and chemokines. This, in turn, provides direction to systematic structural and functional analyses of chemokine-galectin heterodimers. The engineering of stable heterodimers (termed lectinology 4.0 [183] for galectins) would enhance the emerging physiological significance of these new classes of molecular hybrids. 


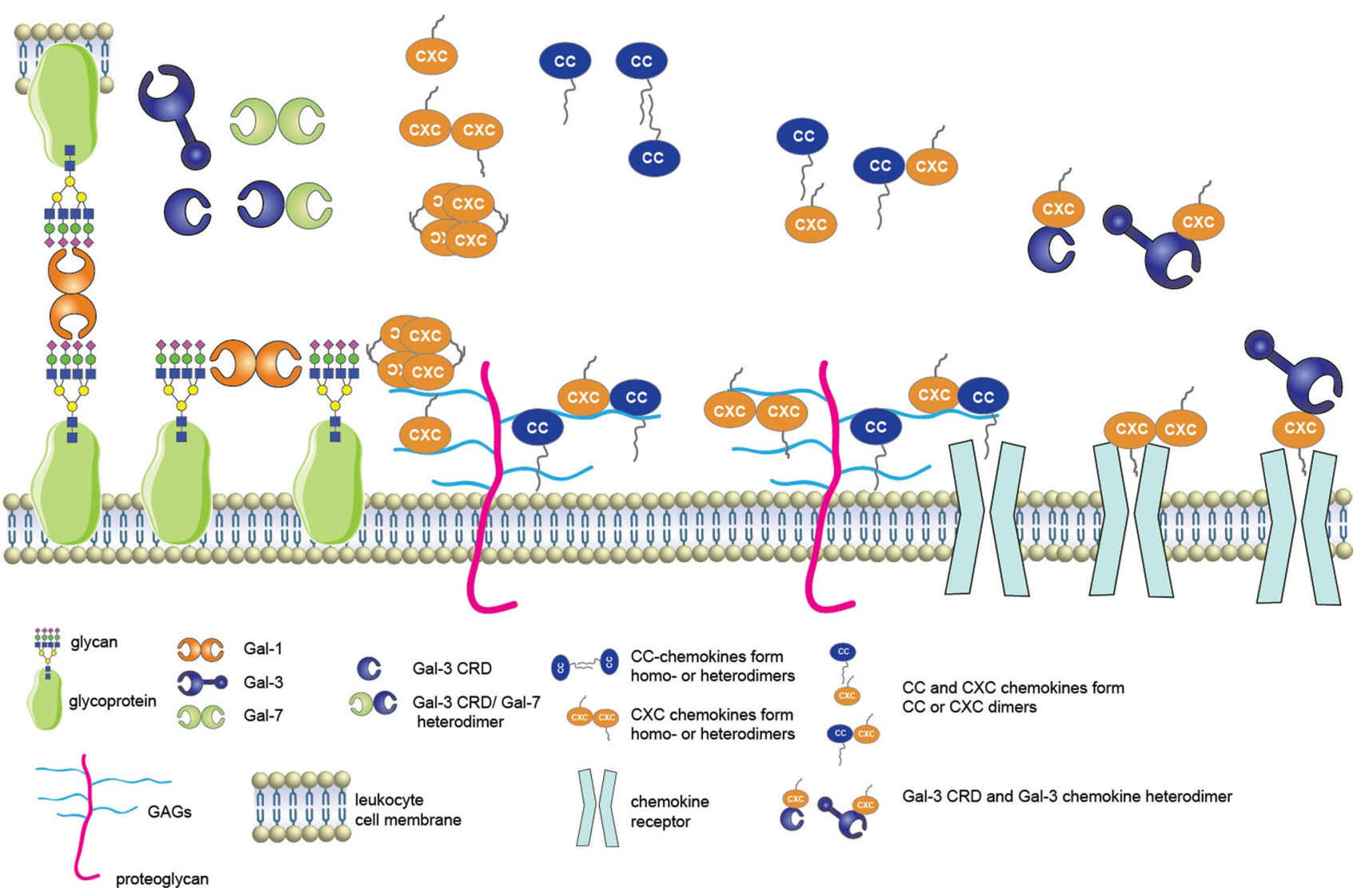

Fig. 11 Schematic illustrating possible structural interactions among chemokines and galectins. Chemokines and galectins can be expressed simultaneously in situ, and their function depends generally on which quaternary structure they have. Prototype galectins (e.g. Gal-1 and Gal-7) normally function extracellularly by crosslinking cell surface glycoproteins in a cis (adjacent) or trans (vis-à vis) fashion. The only chimera-type Gal-3 forms heterodimers both with Gal-7 and with chemokines, including CXCL12. Chemokines exist as monomers, dimers and oligomeric forms with $\mathrm{CC}$ chemokines forming elongated dimeric structures and $\mathrm{CXC}$ chemokines forming more compact dimers. Some chemokines can form heterodimers in a CCor CXC-type dimeric structure. In the CC-type, the N-termini of two chemokines make up a significant portion of the homodimer interface and can thus not enter the chemokine receptor pocket, whereas the $\mathrm{N}$-terminus remains free in CXC homodimers. Chemokines bind to proteoglycan GAG (glycosaminoglycan) chains as monomers or as oligomers; however, in their monomeric form, they cannot bind to the GAG and also activate their receptor at the same time. CXC chemokines can bind to their receptor as monomers and dimers. Some chemokines bind to galectins, including Gal-3 in its fulllength and truncated forms (Gal-3 CRD). Formation of a galectinchemokine heterodimer can result in a change in chemokine receptor activity. In the case of Gal-3 e.g., its interaction with CXCL12 results in inhibition of CXCR4 and chemotaxis 


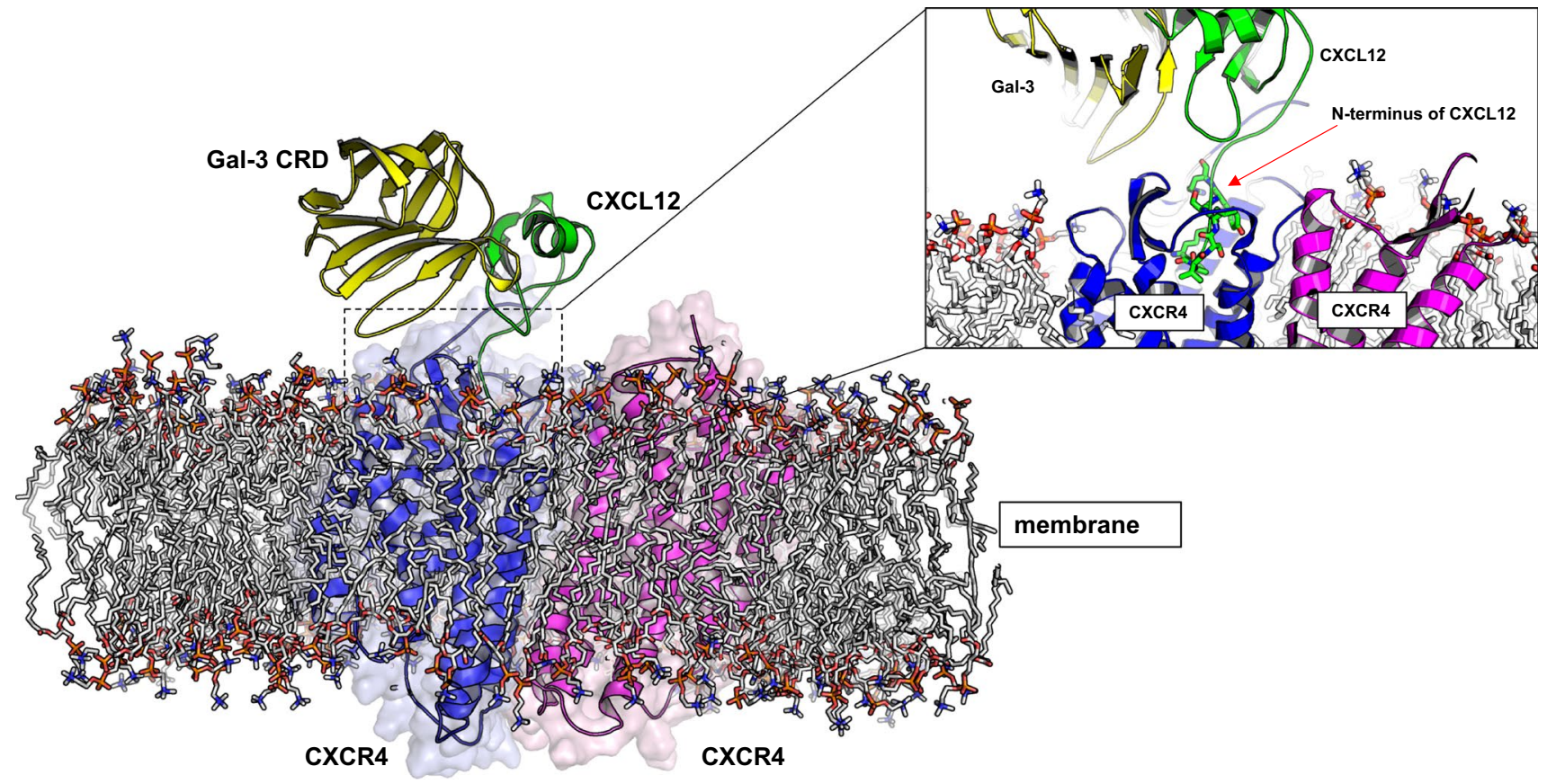

Fig. 12 A model of the ternary complex formed between the homodimeric CXCR4 chemokine receptor and the CXCL12-Gal-3 heterodimer. Insert: a closer look of the model reveals that the $\mathrm{N}$-terminus of

Acknowledgements KHM is Van de Laar professor of structural biology at Maastricht University, The Netherlands. KHM is also grateful to the Ludwig-Maximillian-University (LMU), Munich, Germany, Center for Advanced Study and the Alexander von Humboldt Foundation, Berlin, Germany, for support during his 2019 sabbatical stay at the LMU.

Author contributions $\mathrm{PVH}, \mathrm{HJG}$, and $\mathrm{KHM}$ wrote the manuscript and conceived illustrations. $\mathrm{PVH}$ and $\mathrm{KW}$ generated the figure artwork. PVH, HJG and KHM contributed equally. All authors read, revised and approved the manuscript.

Funding Open Access funding enabled and organized by Projekt DEAL. This work was supported by the National Science Foundation (BIR-961477), the University of Minnesota Medical School and the Minnesota Medical Foundation (K.H.M) and by the Deutsche Forschungsgemeinschaft, SFB1123, A2 (HJG, PvH).

Data availability Not applicable.

\section{Declarations}

Conflict of interests The authors declare no competing interests.

Ethics approval and consent to participate Not applicable.

Consent for publication Not applicable.

Open Access This article is licensed under a Creative Commons Attribution 4.0 International License, which permits use, sharing, adaptation, distribution and reproduction in any medium or format, as long as you give appropriate credit to the original author(s) and the source, provide a link to the Creative Commons licence, and indicate if changes
CXCL12 binds to the CXCR4 receptor without steric hindrance from Gal-3 CRD

were made. The images or other third party material in this article are included in the article's Creative Commons licence, unless indicated otherwise in a credit line to the material. If material is not included in the article's Creative Commons licence and your intended use is not permitted by statutory regulation or exceeds the permitted use, you will need to obtain permission directly from the copyright holder. To view a copy of this licence, visit http://creativecommons.org/licenses/by/4.0/.

\section{References}

1. Hynes RO (2004) The emergence of integrins: a personal and historical perspective. Matrix Biol 23(6):333-340. https://doi. org/10.1016/j.matbio.2004.08.001

2. Hynes RO (2012) The evolution of metazoan extracellular matrix. J Cell Biol 196(6):671-679. https://doi.org/10.1083/jcb. 201109041

3. Johnson MS, Lu N, Denessiouk K, Heino J, Gullberg D (2009) Integrins during evolution: evolutionary trees and model organisms. Biochim Biophys Acta 1788(4):779-789. https://doi.org/ 10.1016/j.bbamem.2008.12.013

4. Theocharis AD, Skandalis SS, Gialeli C, Karamanos NK (2016) Extracellular matrix structure. Adv Drug Deliv Rev 97:4-27. https://doi.org/10.1016/j.addr.2015.11.001

5. Gabius HJ, Roth J (2017) An introduction to the sugar code. Histochem Cell Biol 147(2):111-117. https://doi.org/10.1007/ s00418-016-1521-9

6. Kaltner H, Gabius HJ (2019) Sensing glycans as biochemical messages by tissue lectins: the sugar code at work in vascular biology. Thromb Haemost 119(4):517-533. https://doi.org/10. 1055/s-0038-1676968

7. Bokel C, Brown NH (2002) Integrins in development: moving on, responding to, and sticking to the extracellular matrix. Dev 
Cell 3(3):311-321. https://doi.org/10.1016/s1534-5807(02) 00265-4

8. Hynes RO (2002) Integrins: bidirectional, allosteric signaling machines. Cell 110(6):673-687. https://doi.org/10.1016/s00928674(02)00971-6

9. Prieschl EE, Kulmburg PA, Baumruker T (1995) The nomenclature of chemokines. Int Arch Allergy Immunol 107(4):475483. https://doi.org/10.1159/000237089

10. Ebnet K, Kaldjian EP, Anderson AO, Shaw S (1996) Orchestrated information transfer underlying leukocyte endothelial interactions. Annu Rev Immunol 14:155-177. https://doi.org/ 10.1146/annurev.immunol.14.1.155

11. Ebnet K, Vestweber D (1999) Molecular mechanisms that control leukocyte extravasation: the selectins and the chemokines. Histochem Cell Biol 112(1):1-23. https://doi.org/10.1007/ s004180050387

12. Nelson PJ, Krensky AM (1998) Chemokines, lymphocytes and viruses: what goes around, comes around. Curr Opin Immunol 10(3):265-270. https://doi.org/10.1016/s0952-7915(98) 80164-7

13. Cooper D, Iqbal AJ, Gittens BR, Cervone C, Perretti M (2012) The effect of galectins on leukocyte trafficking in inflammation: sweet or sour? Ann N Y Acad Sci 1253:181-192. https:// doi.org/10.1111/j.1749-6632.2011.06291.x

14. Barondes SH (1997) Galectins: a personal overview. Trends Glycosci Glycotechnol 9(45):1-7. https://doi.org/10.4052/tigg.9.1

15. Thiemann S, Baum LG (2011) The road less traveled: regulation of leukocyte migration across vascular and lymphatic endothelium by galectins. J Clin Immunol 31(1):2-9. https:// doi.org/10.1007/s 10875-010-9460-z

16. Liu FT, Yang RY, Hsu DK (2012) Galectins in acute and chronic inflammation. Ann N Y Acad Sci 1253:80-91. https://doi.org/10. 1111/j.1749-6632.2011.06386.x

17. Thiemann S, Baum LG (2016) Galectins and immune responsesjust how do they do those things they do? Annu Rev Immunol 34:243-264. https://doi.org/10.1146/annurev-immun ol-041015-055402

18. Harrison FL, Chesterton CJ (1980) Factors mediating cell-cell recognition and adhesion. Galaptins, a recently discovered class of bridging molecules. FEBS Lett 122(2):157-165. https://doi. org/10.1016/0014-5793(80)80428-5

19. Yang RY, Liu FT (2003) Galectins in cell growth and apoptosis. Cell Mol Life Sci 60(2):267-276. https://doi.org/10.1007/s0001 80300022

20. Boscher C, Dennis JW, Nabi IR (2011) Glycosylation, galectins and cellular signaling. Curr Opin Cell Biol 23(4):383-392. https://doi.org/10.1016/j.ceb.2011.05.001

21. Kaltner H, Toegel S, Caballero GG, Manning JC, Ledeen RW, Gabius HJ (2017) Galectins: their network and roles in immunity/tumor growth control. Histochem Cell Biol 147(2):239-256. https://doi.org/10.1007/s00418-016-1522-8

22. Demetriou M, Nabi IR, Dennis JW (2018) Galectins as adaptors: linking glycosylation and metabolism with extracellular cues. Trends Glycosci Glycotechnol 30(172):SE167-SE177. https:// doi.org/10.4052/tigg.1732.1SE

23. Kasai K (2018) Galectins: quadruple-faced proteins. Trends Glycosci Glycotechnol 30(172):SE221-SE223. https://doi.org/10. 4052/tigg.1745.7SE

24. de Jong C, Gabius HJ, Baron W (2020) The emerging role of galectins in (re)myelination and its potential for developing new approaches to treat multiple sclerosis. Cell Mol Life Sci 77(7):1289-1317. https://doi.org/10.1007/s00018-019-03327-7

25. Garcia Caballero G, Kaltner H, Kutzner TJ, Ludwig AK, Manning JC, Schmidt S, Sinowatz F, Gabius HJ (2020) How galectins have become multifunctional proteins. Histol Histopathol 35(6):509-539. https://doi.org/10.14670/HH-18-199

26. Sato S, St-Pierre C, Bhaumik P, Nieminen J (2009) Galectins in innate immunity: dual functions of host soluble beta-galactoside-binding lectins as damage-associated molecular patterns (DAMPs) and as receptors for pathogen-associated molecular patterns (PAMPs). Immunol Rev 230(1):172-187. https://doi. org/10.1111/j.1600-065X.2009.00790.x

27. Hong M-H, Weng IC, Liu F-T (2018) Galectins as intracellular regulators of cellular responses through the detection of damaged endocytic vesicles. Trends Glycosci Glycotechnol 30(172):SE179-SE184. https://doi.org/10.4052/tigg.1733.1SE

28. Sato S (2018) Cytosolic galectins and their release and roles as carbohydrate-binding proteins in host-pathogen interaction. Trends Glycosci Glycotechnol 30(172):SE199-SE209. https:// doi.org/10.4052/tigg.1739.1SE

29. Papaspyridonos M, McNeill E, de Bono JP, Smith A, Burnand KG, Channon KM, Greaves DR (2008) Galectin-3 is an amplifier of inflammation in atherosclerotic plaque progression through macrophage activation and monocyte chemoattraction. Arterioscler Thromb Vasc Biol 28(3):433-440. https://doi.org/10.1161/ ATVBAHA.107.159160

30. Masamune A, Satoh M, Hirabayashi J, Kasai K, Satoh K, Shimosegawa T (2006) Galectin-1 induces chemokine production and proliferation in pancreatic stellate cells. Am J Physiol Gastrointest Liver Physiol 290(4):G729-736. https://doi.org/10.1152/ ajpgi.00511.2005

31. Qian D, Lu Z, Xu Q, Wu P, Tian L, Zhao L, Cai B, Yin J, Wu Y, Staveley-O'Carroll KF, Jiang K, Miao Y, Li G (2017) Galectin-1-driven upregulation of SDF-1 in pancreatic stellate cells promotes pancreatic cancer metastasis. Cancer Lett 397:43-51. https://doi.org/10.1016/j.canlet.2017.03.024

32. Filer A, Bik M, Parsonage GN, Fitton J, Trebilcock E, Howlett K, Cook M, Raza K, Simmons DL, Thomas AM, Salmon M, ScheelToellner D, Lord JM, Rabinovich GA, Buckley CD (2009) Galectin 3 induces a distinctive pattern of cytokine and chemokine production in rheumatoid synovial fibroblasts via selective signaling pathways. Arthritis Rheumatol 60(6):1604-1614. https:// doi.org/10.1002/art.24574

33. Toegel S, Weinmann D, Andre S, Walzer SM, Bilban M, Schmidt S, Chiari C, Windhager R, Krall C, Bennani-Baiti IM, Gabius HJ (2016) Galectin-1 couples glycobiology to inflammation in osteoarthritis through the activation of an NF-KB-regulated gene network. J Immunol 196(4):1910-1921. https://doi.org/10.4049/ jimmunol.1501165

34. Weinmann D, Kenn M, Schmidt S, Schmidt K, Walzer SM, Kubista B, Windhager R, Schreiner W, Toegel S, Gabius HJ (2018) Galectin-8 induces functional disease markers in human osteoarthritis and cooperates with galectins- 1 and -3 . Cell Mol Life Sci 75(22):4187-4205. https://doi.org/10.1007/s00018-018-2856-2

35. Chen C, Duckworth CA, Fu B, Pritchard DM, Rhodes JM, Yu LG (2014) Circulating galectins $-2,-4$ and -8 in cancer patients make important contributions to the increased circulation of several cytokines and chemokines that promote angiogenesis and metastasis. Br J Cancer 110(3):741-752. https://doi.org/10.1038/ bjc. 2013.793

36. Cattaneo V, Tribulatti MV, Carabelli J, Carestia A, Schattner M, Campetella O (2014) Galectin-8 elicits pro-inflammatory activities in the endothelium. Glycobiology 24(10):966-973. https:// doi.org/10.1093/glycob/cwu060

37. Carabelli J, Quattrocchi V, D’Antuono A, Zamorano P, Tribulatti MV, Campetella O (2017) Galectin-8 activates dendritic cells and stimulates antigen-specific immune response elicitation. J Leukoc Biol 102(5):1237-1247. https://doi.org/10.1189/jlb. 3A0816-357RR 
38. Petrie Aronin CE, Zhao YM, Yoon JS, Morgan NY, Prustel T, Germain RN, Meier-Schellersheim M (2017) Migrating myeloid cells sense temporal dynamics of chemoattractant concentrations. Immunity 47(5):862-874 e863. https://doi.org/10.1016/j.immuni. 2017.10.020

39. Ridley AJ, Schwartz MA, Burridge K, Firtel RA, Ginsberg MH, Borisy G, Parsons JT, Horwitz AR (2003) Cell migration: integrating signals from front to back. Science 302(5651):17041709. https://doi.org/10.1126/science. 1092053

40. Reversat A, Gaertner F, Merrin J, Stopp J, Tasciyan S, Aguilera J, de Vries I, Hauschild R, Hons M, Piel M, Callan-Jones A, Voituriez R, Sixt M (2020) Cellular locomotion using environmental topography. Nature 582(7813):582-585. https://doi.org/10.1038/ s41586-020-2283-z

41. Aoun L, Farutin A, Garcia-Seyda N, Negre P, Rizvi MS, Tlili S, Song S, Luo X, Biarnes-Pelicot M, Galland R, Sibarita JB, Michelot A, Hivroz C, Rafai S, Valignat MP, Misbah C, Theodoly O (2020) Amoeboid swimming is propelled by molecular paddling in lymphocytes. Biophys J 119(6):1157-1177. https://doi.org/10. 1016/j.bpj.2020.07.033

42. Weber M, Hauschild R, Schwarz J, Moussion C, de Vries I, Legler DF, Luther SA, Bollenbach T, Sixt M (2013) Interstitial dendritic cell guidance by haptotactic chemokine gradients. Science 339(6117):328-332. https://doi.org/10.1126/science.12284 56

43. Saravanan C, Liu FT, Gipson IK, Panjwani N (2009) Galectin-3 promotes lamellipodia formation in epithelial cells by interacting with complex $\mathrm{N}$-glycans on $\alpha 3 \beta 1$ integrin. J Cell Sci 122(Pt 20):3684-3693. https://doi.org/10.1242/jcs.045674

44. Rorive S, Belot N, Decaestecker C, Lefranc F, Gordower L, Micik S, Maurage CA, Kaltner H, Ruchoux MM, Danguy A, Gabius HJ, Salmon I, Kiss R, Camby I (2001) Galectin-1 is highly expressed in human gliomas with relevance for modulation of invasion of tumor astrocytes into the brain parenchyma. Glia 33(3):241-255. https://doi.org/10.1002/1098-1136(200103) 33:3\%3c241::aid-glia1023\%3e3.0.co;2-1

45. Camby I, Belot N, Lefranc F, Sadeghi N, Launoit Y, Kaltner H, Musette S, Darro F, Danguy A, Salmon I, Gabius H-J, Kiss R (2002) Galectin-1 modulates human glioblastoma cell migration into the brain through modifications to the actin cytoskeleton and levels of expression of small GTPases. J Neuropathol Exp Neurol 61:585-596. https://doi.org/10.1093/jnen/61.7.585

46. Metz C, Doger R, Riquelme E, Cortes P, Holmes C, Shaughnessy R, Oyanadel C, Grabowski C, Gonzalez A, Soza A (2016) Galectin-8 promotes migration and proliferation and prevents apoptosis in U87 glioblastoma cells. Biol Res 49(1):33. https://doi.org/10. 1186/s40659-016-0091-6

47. Nagy N, Bronckart Y, Camby I, Legendre H, Lahm H, Kaltner H, Hadari Y, Van Ham P, Yeaton P, Pector JC, Zick Y, Salmon I, Danguy A, Kiss R, Gabius HJ (2002) Galectin-8 expression decreases in cancer compared with normal and dysplastic human colon tissue and acts significantly on human colon cancer cell migration as a suppressor. Gut 50(3):392-401. https://doi.org/ 10.1136/gut.50.3.392

48. Levine SP, Wohl H (1976) Human platelet factor 4: purification and characterization by affinity chromatography. Purification of human platelet factor 4. J Biol Chem 251(2):324-328

49. Hermodson M, Schmer G, Kurachi K (1977) Isolation, crystallization, and primary amino acid sequence of human platelet factor 4. J Biol Chem 252(18):6276-6279

50. Walz DA, Wu VY, de Lamo R, Dene H, McCoy LE (1977) Primary structure of human platelet factor 4 . Thromb Res 11(6):893-898. https://doi.org/10.1016/0049-3848(77)90117-7

51. Altman LC, Snyderman R, Oppenheim JJ, Mergenhagen SE (1973) A human mononuclear leukocyte chemotactic factor: characterization, specificity and kinetics of production by homologous leukocytes. J Immunol 110(3):801-810

52. Oppenheim JJ, Zachariae CO, Mukaida N, Matsushima K (1991) Properties of the novel proinflammatory supergene "intercrine" cytokine family. Annu Rev Immunol 9:617-648. https://doi.org/ 10.1146/annurev.iy.09.040191.003153

53. Schall TJ (1991) Biology of the RANTES/SIS cytokine family. Cytokine 3(3):165-183. https://doi.org/10.1016/1043-4666(91) 90013-4

54. Kunkel SL, Strieter RM, Lindley IJ, Westwick J (1995) Chemokines: new ligands, receptors and activities. Immunol Today 16(12):559-561. https://doi.org/10.1016/0167-5699(95) 80076-X

55. Murphy PM, Baggiolini M, Charo IF, Hebert CA, Horuk R, Matsushima K, Miller LH, Oppenheim JJ, Power CA (2000) International union of pharmacology. XXII. Nomenclature for chemokine receptors. Pharmacol Rev 52(1):145-176

56. Bachelerie F, Graham GJ, Locati M, Mantovani A, Murphy PM, Nibbs R, Rot A, Sozzani S, Thelen M (2014) New nomenclature for atypical chemokine receptors. Nat Immunol 15(3):207-208. https://doi.org/10.1038/ni.2812

57. Hughes CE, Nibbs RJB (2018) A guide to chemokines and their receptors. FEBS J 285(16):2944-2971. https://doi.org/10.1111/ febs. 14466

58. Kapurniotu A, Gokce O, Bernhagen J (2019) The multitasking potential of alarmins and atypical chemokines. Front Med (Lausanne) 6:3. https://doi.org/10.3389/fmed.2019.00003

59. Mayo KH, Chen MJ (1989) Human platelet factor 4 monomerdimer-tetramer equilibria investigated by $1 \mathrm{H}$ NMR spectroscopy. Biochemistry 28(24):9469-9478. https://doi.org/10.1021/bi004 $50 \mathrm{a} 034$

60. Chen MJ, Mayo KH (1991) Human platelet factor 4 subunit association/dissociation thermodynamics and kinetics. Biochemistry 30(26):6402-6411. https://doi.org/10.1021/bi00240a009

61. Clore GM, Gronenborn AM (1995) Three-dimensional structures of $\alpha$ and $\beta$ chemokines. FASEB J 9(1):57-62. https://doi.org/10. 1096/fasebj.9.1.7821760

62. Meunier S, Bernassau JM, Guillemot JC, Ferrara P, Darbon $H$ (1997) Determination of the three-dimensional structure of $\mathrm{CC}$ chemokine monocyte chemoattractant protein 3 by $1 \mathrm{H}$ twodimensional NMR spectroscopy. Biochemistry 36(15):44124422. https://doi.org/10.1021/bi9627929

63. Hoover DM, Boulegue C, Yang D, Oppenheim JJ, Tucker K, $\mathrm{Lu}$ W, Lubkowski J (2002) The structure of human macrophage inflammatory protein-3 $\alpha$ /CCL20. Linking antimicrobial and CC chemokine receptor-6-binding activities with human $\beta$-defensins. J Biol Chem 277(40):37647-37654. https://doi.org/10.1074/jbc. M203907200

64. Lubkowski J, Bujacz G, Boque L, Domaille PJ, Handel TM, Wlodawer A (1997) The structure of MCP-1 in two crystal forms provides a rare example of variable quaternary interactions. Nat Struct Biol 4(1):64-69. https://doi.org/10.1038/nsb0197-64

65. Jansma AL, Kirkpatrick JP, Hsu AR, Handel TM, Nietlispach D (2010) NMR analysis of the structure, dynamics, and unique oligomerization properties of the chemokine CCL27. J Biol Chem 285(19):14424-14437. https://doi.org/10.1074/jbc.M109.091108

66. Murphy JW, Yuan H, Kong Y, Xiong Y, Lolis EJ (2010) Heterologous quaternary structure of CXCL12 and its relationship to the CC chemokine family. Proteins 78(5):1331-1337. https://doi. org/10.1002/prot.22666

67. Mayo KH (1991) Low-affinity platelet factor 4 1H NMR derived aggregate equilibria indicate a physiologic preference for monomers over dimers and tetramers. Biochemistry 30(4):925-934. https://doi.org/10.1021/bi00218a007

68. Yang Y, Mayo KH, Daly TJ, Barry JK, La Rosa GJ (1994) Subunit association and structural analysis of platelet basic protein 
and related proteins investigated by $1 \mathrm{H}$ NMR spectroscopy and circular dichroism. J Biol Chem 269(31):20110-20118

69. Lit LC, Wong CK, Tam LS, Li EK, Lam CW (2006) Raised plasma concentration and ex vivo production of inflammatory chemokines in patients with systemic lupus erythematosus. Ann Rheum Dis 65(2):209-215. https://doi.org/10.1136/ard. 2005.038315

70. Blanchet X, Cesarek K, Brandt J, Herwald H, Teupser D, Kuchenhoff H, Karshovska E, Mause SF, Siess W, Wasmuth $\mathrm{H}$, Soehnlein O, Koenen RR, Weber C, von Hundelshausen $P$ (2014) Inflammatory role and prognostic value of platelet chemokines in acute coronary syndrome. Thromb Haemost 112(6):1277-1287. https://doi.org/10.1160/TH14-02-0139

71. Proudfoot AE, Handel TM, Johnson Z, Lau EK, LiWang P, Clark-Lewis I, Borlat F, Wells TN, Kosco-Vilbois MH (2003) Glycosaminoglycan binding and oligomerization are essential for the in vivo activity of certain chemokines. Proc Natl Acad Sci USA 100(4):1885-1890. https://doi.org/10.1073/pnas. 0334864100

72. Veldkamp CT, Peterson FC, Pelzek AJ, Volkman BF (2005) The monomer-dimer equilibrium of stromal cell-derived factor-1 (CXCL12) is altered by $\mathrm{pH}$, phosphate, sulfate, and heparin. Protein Sci 14(4):1071-1081. https://doi.org/10.1110/ps. 041219505

73. Brown AJ, Sepuru KM, Sawant KV, Rajarathnam K (2017) Platelet-derived chemokine cxcl7 dimer preferentially exists in the glycosaminoglycan-bound form: implications for neutrophil-platelet crosstalk. Front Immunol 8:1248. https://doi. org/10.3389/fimmu.2017.01248

74. Liang WG, Triandafillou CG, Huang TY, Zulueta MM, Banerjee S, Dinner AR, Hung SC, Tang WJ (2016) Structural basis for oligomerization and glycosaminoglycan binding of CCL5 and CCL3. Proc Natl Acad Sci USA 113(18):5000-5005. https://doi.org/10.1073/pnas.1523981113

75. Yang Y, Barker S, Chen MJ, Mayo KH (1993) Effect of low molecular weight aliphatic alcohols and related compounds on platelet factor 4 subunit association. J Biol Chem 268(13):9223-9229. https://doi.org/10.1016/S0021-9258(18) 98339-0

76. Wang X, Sharp JS, Handel TM, Prestegard JH (2013) Chemokine oligomerization in cell signaling and migration. Prog Mol Biol Transl Sci 117:531-578. https://doi.org/10.1016/B978-0-12386931-9.00020-9

77. Salanga CL, O'Hayre M, Handel T (2009) Modulation of chemokine receptor activity through dimerization and crosstalk. Cell Mol Life Sci 66(8):1370-1386. https://doi.org/10.1007/ s00018-008-8666-1

78. Hoogewerf AJ, Kuschert GS, Proudfoot AE, Borlat F, ClarkLewis I, Power CA, Wells TN (1997) Glycosaminoglycans mediate cell surface oligomerization of chemokines. Biochemistry 36(44):13570-13578. https://doi.org/10.1021/bi971125s

79. Rajarathnam K, Desai UR (2020) Structural insights into how proteoglycans determine chemokine-CXCR1/CXCR2 interactions: progress and challenges. Front Immunol 11:660. https:// doi.org/10.3389/fimmu.2020.00660

80. Rajarathnam K, Sykes BD, Kay CM, Dewald B, Geiser T, Baggiolini M, Clark-Lewis I (1994) Neutrophil activation by monomeric interleukin-8. Science 264(5155):90-92. https://doi.org/ $10.1126 /$ science. 8140420

81. Nasser MW, Raghuwanshi SK, Grant DJ, Jala VR, Rajarathnam K, Richardson RM (2009) Differential activation and regulation of CXCR 1 and CXCR2 by CXCL8 monomer and dimer. J Immunol 183(5):3425-3432. https://doi.org/10.4049/jimmunol.09003 05

82. Paavola CD, Hemmerich S, Grunberger D, Polsky I, Bloom A, Freedman R, Mulkins M, Bhakta S, McCarley D, Wiesent L,
Wong B, Jarnagin K, Handel TM (1998) Monomeric monocyte chemoattractant protein-1 (MCP-1) binds and activates the MCP-1 receptor CCR2B. J Biol Chem 273(50):33157-33165. https://doi.org/10.1074/jbc.273.50.33157

83. Ravindran A, Sawant KV, Sarmiento J, Navarro J, Rajarathnam $\mathrm{K}$ (2013) Chemokine CXCL1 dimer is a potent agonist for the CXCR2 receptor. J Biol Chem 288(17):12244-12252. https:// doi.org/10.1074/jbc.M112.443762

84. Drury LJ, Ziarek JJ, Gravel S, Veldkamp CT, Takekoshi T, Hwang ST, Heveker N, Volkman BF, Dwinell MB (2011) Monomeric and dimeric CXCL12 inhibit metastasis through distinct CXCR4 interactions and signaling pathways. Proc Natl Acad Sci USA 108(43):17655-17660. https://doi.org/10.1073/ pnas. 1101133108

85. Liu K, Wu L, Yuan S, Wu M, Xu Y, Sun Q, Li S, Zhao S, Hua T, Liu ZJ (2020) Structural basis of CXC chemokine receptor 2 activation and signalling. Nature 585(7823):135-140. https:// doi.org/10.1038/s41586-020-2492-5

86. Ren C, Yuan Q, Braun M, Zhang X, Petri B, Zhang J, Kim D, Guez-Haddad J, Xue W, Pan W, Fan R, Kubes P, Sun Z, Opatowsky Y, Polleux F, Karatekin E, Tang W, Wu D (2019) Leukocyte cytoskeleton polarization is initiated by plasma membrane curvature from cell attachment. Dev Cell 49(2):206219 e207. https://doi.org/10.1016/j.devcel.2019.02.023

87. Lortat-Jacob H, Grosdidier A, Imberty A (2002) Structural diversity of heparan sulfate binding domains in chemokines. Proc Natl Acad Sci USA 99(3):1229-1234. https://doi.org/10. 1073/pnas.032497699

88. Mayo KH, Roongta V, Ilyina E, Milius R, Barker S, Quinlan C, La Rosa G, Daly TJ (1995) NMR solution structure of the 32-kDa platelet factor 4 ELR-motif N-terminal chimera: a symmetric tetramer. Biochemistry 34(36):11399-11409. https:// doi.org/10.1021/bi00036a012

89. Murphy JW, Cho Y, Sachpatzidis A, Fan C, Hodsdon ME, Lolis E (2007) Structural and functional basis of CXCL12 (stromal cell-derived factor- $1 \alpha$ ) binding to heparin. J Biol Chem 282(13):10018-10027. https://doi.org/10.1074/jbc.M6087 96200

90. Rek A, Brandner B, Geretti E, Kungl AJ (2009) A biophysical insight into the RANTES-glycosaminoglycan interaction. Biochim Biophys Acta 1794(4):577-582. https://doi.org/10.1016/j. bbapap.2009.01.001

91. Dyer DP, Salanga CL, Volkman BF, Kawamura T, Handel TM (2016) The dependence of chemokine-glycosaminoglycan interactions on chemokine oligomerization. Glycobiology 26(3):312326. https://doi.org/10.1093/glycob/cwv100

92. Seo Y, Andaya A, Bleiholder C, Leary JA (2013) Differentiation of CC vs CXC chemokine dimers with GAG octasaccharide binding partners: an ion mobility mass spectrometry approach. J Am Chem Soc 135(11):4325-4332. https://doi.org/10.1021/ ja310915m

93. Salanga CL, Handel TM (2011) Chemokine oligomerization and interactions with receptors and glycosaminoglycans: the role of structural dynamics in function. Exp Cell Res 317(5):590-601. https://doi.org/10.1016/j.yexcr.2011.01.004

94. Crown SE, Yu Y, Sweeney MD, Leary JA, Handel TM (2006) Heterodimerization of CCR 2 chemokines and regulation by glycosaminoglycan binding. J Biol Chem 281(35):25438-25446. https://doi.org/10.1074/jbc.M601518200

95. Mikhailov D, Young HC, Linhardt RJ, Mayo KH (1999) Heparin dodecasaccharide binding to platelet factor-4 and growthrelated protein- $\alpha$. Induction of a partially folded state and implications for heparin-induced thrombocytopenia. J Biol Chem 274(36):25317-25329. https://doi.org/10.1074/jbc.274.36.25317

96. Graham GJ, Handel TM, Proudfoot AEI (2019) Leukocyte adhesion: reconceptualizing chemokine presentation by 
glycosaminoglycans. Trends Immunol 40(6):472-481. https:// doi.org/10.1016/j.it.2019.03.009

97. Nesmelova IV, Sham Y, Gao J, Mayo KH (2008) CXC and CC chemokines form mixed heterodimers: association free energies from molecular dynamics simulations and experimental correlations. J Biol Chem 283(35):24155-24166. https://doi.org/10. 1074/jbc.M803308200

98. Nesmelova IV, Sham Y, Dudek AZ, van Eijk LI, Wu G, Slungaard A, Mortari F, Griffioen AW, Mayo KH (2005) Platelet factor 4 and interleukin-8 CXC chemokine heterodimer formation modulates function at the quaternary structural level. J Biol Chem 280(6):4948-4958. https://doi.org/10.1074/jbc.M4053 64200

99. Dudek AZ, Nesmelova I, Mayo K, Verfaillie CM, Pitchford S, Slungaard A (2003) Platelet factor 4 promotes adhesion of hematopoietic progenitor cells and binds IL-8: novel mechanisms for modulation of hematopoiesis. Blood 101(12):4687-4694. https://doi.org/10.1182/blood-2002-08-2363

100. Brown AJ, Joseph PR, Sawant KV, Rajarathnam K (2017) Chemokine CXCL7 heterodimers: structural insights, CXCR2 receptor function, and glycosaminoglycan interactions. Int $\mathrm{J}$ Mol Sci 18(4):748. https://doi.org/10.3390/ijms18040748

101. Koenen RR, von Hundelshausen P, Nesmelova IV, Zernecke A, Liehn EA, Sarabi A, Kramp BK, Piccinini AM, Paludan SR, Kowalska MA, Kungl AJ, Hackeng TM, Mayo KH, Weber C (2009) Disrupting functional interactions between platelet chemokines inhibits atherosclerosis in hyperlipidemic mice. Nat Med 15(1):97-103. https://doi.org/10.1038/nm.1898

102. von Hundelshausen P, Agten SM, Eckardt V, Blanchet X, Schmitt MM, Ippel H, Neideck C, Bidzhekov K, Leberzammer J, Wichapong K, Faussner A, Drechsler M, Grommes J, van Geffen JP, Li H, Ortega-Gomez A, Megens RT, Naumann R, Dijkgraaf I, Nicolaes GA, Doring Y, Soehnlein O, Lutgens E, Heemskerk JW, Koenen RR, Mayo KH, Hackeng TM, Weber C (2017) Chemokine interactome mapping enables tailored intervention in acute and chronic inflammation. Sci Transl Med 9(384):eaah6650. https://doi.org/10.1126/scitranslmed.aah6650

103. Guan E, Wang J, Norcross MA (2001) Identification of human macrophage inflammatory proteins 1 alpha and 1 beta as a native secreted heterodimer. J Biol Chem 276(15):12404-12409. https://doi.org/10.1074/jbc.M006327200

104. Jansma A, Handel TM, Hamel DJ (2009) Chapter 2. Homoand hetero-oligomerization of chemokines. Methods Enzymol 461:31-50. https://doi.org/10.1016/S0076-6879(09)05402-0

105. Sepuru KM, Rajarathnam K (2021) Structural basis of a chemokine heterodimer binding to glycosaminoglycans. Biochem J 478(5):1009-1021. https://doi.org/10.1042/BCJ20200927

106. Brown AJ, Sepuru KM, Rajarathnam K (2017) Structural basis of native CXCL7 monomer binding to CXCR2 receptor $\mathrm{N}$-domain and glycosaminoglycan heparin. Int J Mol Sci. https://doi.org/10. 3390/ijms 18030508

107. Gengrinovitch S, Greenberg SM, Cohen T, Gitay-Goren H, Rockwell P, Maione TE, Levi BZ, Neufeld G (1995) Platelet factor-4 inhibits the mitogenic activity of VEGF121 and VEGF165 using several concurrent mechanisms. J Biol Chem 270(25):1505915065. https://doi.org/10.1074/jbc.270.25.15059

108. Dudek AZ, Pennell CA, Decker TD, Young TA, Key NS, Slungaard A (1997) Platelet factor 4 binds to glycanated forms of thrombomodulin and to protein C. A potential mechanism for enhancing generation of activated protein C. J Biol Chem 272(50):31785-31792. https://doi.org/10.1074/jbc.272.50.31785

109. Perollet C, Han ZC, Savona C, Caen JP, Bikfalvi A (1998) Platelet factor 4 modulates fibroblast growth factor 2 (FGF-2) activity and inhibits FGF-2 dimerization. Blood 91(9):3289-3299

110. von Hundelshausen P, Koenen RR, Sack M, Mause SF, Adriaens W, Proudfoot AE, Hackeng TM, Weber C (2005)
Heterophilic interactions of platelet factor 4 and RANTES promote monocyte arrest on endothelium. Blood 105(3):924-930. https://doi.org/10.1182/blood-2004-06-2475

111. Qin L, Kufareva I, Holden LG, Wang C, Zheng Y, Zhao C, Fenalti G, Wu H, Han GW, Cherezov V, Abagyan R, Stevens RC, Handel TM (2015) Crystal structure of the chemokine receptor CXCR4 in complex with a viral chemokine. Science 347(6226):1117-1122. https://doi.org/10.1126/science.12610 64

112. Wasilko DJ, Johnson ZL, Ammirati M, Che Y, Griffor MC, Han S, Wu H (2020) Structural basis for chemokine receptor CCR6 activation by the endogenous protein ligand CCL20. Nat Commun 11(1):3031. https://doi.org/10.1038/s41467-020-16820-6

113. Zheng Y, Qin L, Zacarias NV, de Vries H, Han GW, Gustavsson M, Dabros M, Zhao C, Cherney RJ, Carter P, Stamos D, Abagyan R, Cherezov V, Stevens RC, AP IJ, Heitman LH, Tebben A, Kufareva I, Handel TM, (2016) Structure of CC chemokine receptor 2 with orthosteric and allosteric antagonists. Nature 540(7633):458-461. https://doi.org/10.1038/nature20605

114. Zheng Y, Han GW, Abagyan R, Wu B, Stevens RC, Cherezov V, Kufareva I, Handel TM (2017) Structure of CC chemokine receptor 5 with a potent chemokine antagonist reveals mechanisms of chemokine recognition and molecular mimicry by HIV. Immunity 46(6):1005-1017 e1005. https://doi.org/10.1016/j.immuni. 2017.05.002

115. Bhusal RP, Foster SR, Stone MJ (2020) Structural basis of chemokine and receptor interactions: key regulators of leukocyte recruitment in inflammatory responses. Protein Sci 29(2):420 432. https://doi.org/10.1002/pro.3744

116. Sepuru KM, Nair V, Prakash P, Gorfe AA, Rajarathnam K (2020) Long-range coupled motions underlie ligand recognition by a chemokine receptor. iScience 23(12):101858-101858. https:// doi.org/10.1016/j.isci.2020.101858

117. Abayev M, Rodrigues JPGLM, Srivastava G, Arshava B, Jaremko Ł, Jaremko M, Naider F, Levitt M, Anglister J (2018) The solution structure of monomeric CCL5 in complex with a doubly sulfated N-terminal segment of CCR5. FEBS J 285(11):1988-2003. https://doi.org/10.1111/febs.14460

118. Ziarek JJ, Kleist AB, London N, Raveh B, Montpas N, Bonneterre J, St-Onge G, DiCosmo-Ponticello CJ, Koplinski CA, Roy I, Stephens B, Thelen S, Veldkamp CT, Coffman FD, Cohen MC, Dwinell MB, Thelen M, Peterson FC, Heveker N, Volkman BF (2017) Structural basis for chemokine recognition by a G proteincoupled receptor and implications for receptor activation. Sci Signal. https://doi.org/10.1126/scisignal.aah5756

119. Katritch V, Cherezov V, Stevens RC (2013) Structure-function of the G protein-coupled receptor superfamily. Annu Rev Pharmacol Toxicol 53:531-556. https://doi.org/10.1146/annurev-pharm tox-032112-135923

120. Corbisier J, Gales C, Huszagh A, Parmentier M, Springael JY (2015) Biased signaling at chemokine receptors. J Biol Chem 290(15):9542-9554. https://doi.org/10.1074/jbc.M114.596098

121. Kenakin $T$ (2019) Biased receptor signaling in drug discovery. Pharmacol Rev 71(2):267-315. https://doi.org/10.1124/pr.118. 016790

122. Busillo JM, Armando S, Sengupta R, Meucci O, Bouvier M, Benovic JL (2010) Site-specific phosphorylation of CXCR4 is dynamically regulated by multiple kinases and results in differential modulation of CXCR4 signaling. J Biol Chem 285(10):78057817. https://doi.org/10.1074/jbc.M109.091173

123. Smith JS, Lefkowitz RJ, Rajagopal S (2018) Biased signalling: from simple switches to allosteric microprocessors. Nat Rev Drug Discov 17(4):243-260. https://doi.org/10.1038/nrd.2017. 229

124. Lagane B, Chow KY, Balabanian K, Levoye A, Harriague J, Planchenault T, Baleux F, Gunera-Saad N, Arenzana-Seisdedos 
F, Bachelerie F (2008) CXCR4 dimerization and $\beta$-arrestinmediated signaling account for the enhanced chemotaxis to CXCL12 in WHIM syndrome. Blood 112(1):34-44. https:// doi.org/10.1182/blood-2007-07-102103

125. Thelen M, Munoz LM, Rodriguez-Frade JM, Mellado M (2010) Chemokine receptor oligomerization: functional considerations. Curr Opin Pharmacol 10(1):38-43. https://doi.org/ 10.1016/j.coph.2009.09.004

126. Sohy D, Yano H, de Nadai P, Urizar E, Guillabert A, Javitch JA, Parmentier M, Springael JY (2009) Hetero-oligomerization of CCR2, CCR5, and CXCR4 and the protean effects of "selective" antagonists. J Biol Chem 284(45):31270-31279. https:// doi.org/10.1074/jbc.M109.054809

127. Hernanz-Falcon P, Rodriguez-Frade JM, Serrano A, Juan D, del Sol A, Soriano SF, Roncal F, Gomez L, Valencia A, Martinez AC, Mellado M (2004) Identification of amino acid residues crucial for chemokine receptor dimerization. Nat Immunol 5(2):216-223. https://doi.org/10.1038/ni1027

128. Sohy D, Parmentier M, Springael JY (2007) Allosteric transinhibition by specific antagonists in CCR2/CXCR4 heterodimers. J Biol Chem 282(41):30062-30069. https://doi.org/10.1074/ jbc.M705302200

129. Raman D, Sobolik-Delmaire T, Richmond A (2011) Chemokines in health and disease. Exp Cell Res 317(5):575589. https://doi.org/10.1016/j.yexcr.2011.01.005

130. Schwarz HP, Dorner F (2003) Karl Landsteiner and his major contributions to haematology. Br J Haematol 121(4):556-565. https://doi.org/10.1046/j.1365-2141.2003.04295.x

131. Boyd WC, Shapleigh E (1954) Specific precipitating activity of plant agglutinins (lectins). Science 119(3091):419. https:// doi.org/10.1126/science.119.3091.419

132. Boyd WC (1963) The lectins: their present status. Vox Sang 8:1-32. https://doi.org/10.1111/j.1423-0410.1963.tb04146.x

133. Kilpatrick DC, Green C (1992) Lectins as blood typing reagents. Adv Lectin Res 5:51-94

134. Kaltner H, Garcia Caballero G, Ludwig AK, Manning JC, Gabius HJ (2018) From glycophenotyping by (plant) lectin histochemistry to defining functionality of glycans by pairing with endogenous lectins. Histochem Cell Biol 149(6):547-568. https://doi.org/10.1007/s00418-018-1676-7

135. Watkins WM (1999) A half century of blood-group antigen research. Some personal recollections. Trends Glycosci Glycotechnol 11(62):391-411. https://doi.org/10.4052/tigg.11.391

136. Teichberg VI, Silman I, Beitsch DD, Resheff G (1975) A $\beta$-Dgalactoside binding protein from electric organ tissue of Electrophorus electricus. Proc Natl Acad Sci USA 72(4):13831387. https://doi.org/10.1073/pnas.72.4.1383

137. Drickamer K (1988) Two distinct classes of carbohydrate-recognition domains in animal lectins. J Biol Chem 263(20):9557-9560

138. Cooper DNW (2002) Galectinomics: finding themes in complexity. Biochim Biophys Acta 1572(2-3):209-231. https://doi. org/10.1016/s0304-4165(02)00310-0

139. Manning JC, Garcia Caballero G, Knospe C, Kaltner H, Gabius HJ (2017) Network analysis of adhesion/growth-regulatory galectins and their binding sites in adult chicken retina and choroid. J Anat 231(1):23-37. https://doi.org/10.1111/joa. 12612

140. Habermann FA, Kaltner H, Higuero AM, García Caballero G, Ludwig A-K, Manning JC, Abad-Rodríguez J, Gabius H-J (2021) What cyto- and histochemistry can do to crack the sugar code. Acta Histochem Cytochem 54(2):31-48. https://doi.org/ 10.1267/ahc.21-00017

141. Lobsanov YD, Rini JM (1997) Galectin structure. Trends Glycosci Glycotechnol 9(45):145-154. https://doi.org/10.4052/ tigg.9.145
142. Kamitori S (2018) Three-dimensional structures of galectins. Trends Glycosci Glycotechnol 30(172):SE41-SE50. https://doi. org/10.4052/tigg.1731.1SE

143. Romero A, Gabius HJ (2019) Galectin-3: is this member of a large family of multifunctional lectins (already) a therapeutic target? Expert Opin Ther Targets 23(10):819-828. https://doi. org/10.1080/14728222.2019.1675638

144. Kasai K, Hirabayashi J (1996) Galectins: a family of animal lectins that decipher glycocodes. J Biochem 119(1):1-8. https://doi. org/10.1093/oxfordjournals.jbchem.a021192

145. Hirabayashi J, Kasai KI (1998) Evolution of animal lectins. Prog Mol Subcell Biol 19:45-88. https://doi.org/10.1007/ 978-3-642-48745-3_3

146. Miller MC, Ribeiro JP, Roldos V, Martin-Santamaria S, Canada FJ, Nesmelova IA, Andre S, Pang M, Klyosov AA, Baum LG, Jimenez-Barbero J, Gabius HJ, Mayo KH (2011) Structural aspects of binding of $\alpha$-linked digalactosides to human galectin-1. Glycobiology 21(12):1627-1641. https://doi.org/10.1093/ glycob/cwr083

147. Miller MC, Klyosov A, Mayo KH (2009) The $\alpha$-galactomannan Davanat binds galectin- 1 at a site different from the conventional galectin carbohydrate binding domain. Glycobiology 19(9):1034-1045. https://doi.org/10.1093/glycob/cwp084

148. Miller MC, Nesmelova IV, Platt D, Klyosov A, Mayo KH (2009) The carbohydrate-binding domain on galectin-1 is more extensive for a complex glycan than for simple saccharides: implications for galectin-glycan interactions at the cell surface. Biochem J 421(2):211-221. https://doi.org/10.1042/BJ20090265

149. Miller MC, Ippel H, Suylen D, Klyosov AA, Traber PG, Hackeng T, Mayo KH (2016) Binding of polysaccharides to human galectin-3 at a noncanonical site in its carbohydrate recognition domain. Glycobiology 26(1):88-99. https://doi.org/10.1093/glycob/cwv073

150. Ahmad N, Gabius HJ, Andre S, Kaltner H, Sabesan S, Roy R, Liu B, Macaluso F, Brewer CF (2004) Galectin-3 precipitates as a pentamer with synthetic multivalent carbohydrates and forms heterogeneous cross-linked complexes. J Biol Chem 279(12):10841-10847. https://doi.org/10.1074/jbc.M312834200

151. Kopitz J, von Reitzenstein C, Andre S, Kaltner H, Uhl J, Ehemann V, Cantz M, Gabius HJ (2001) Negative regulation of neuroblastoma cell growth by carbohydrate-dependent surface binding of galectin-1 and functional divergence from galectin-3. J Biol Chem 276(38):35917-35923. https://doi.org/10.1074/jbc. M105135200

152. Ludwig AK, Michalak M, Xiao Q, Gilles U, Medrano FJ, Ma H, FitzGerald FG, Hasley WD, Melendez-Davila A, Liu M, Rahimi K, Kostina NY, Rodriguez-Emmenegger C, Moller M, Lindner I, Kaltner H, Cudic M, Reusch D, Kopitz J, Romero A, Oscarson S, Klein ML, Gabius HJ, Percec V (2019) Design-functionality relationships for adhesion/growth-regulatory galectins. Proc Natl Acad Sci USA 116(8):2837-2842. https://doi.org/10.1073/pnas. 1813515116

153. Gabius HJ, Manning JC, Kopitz J, Andre S, Kaltner H (2016) Sweet complementarity: the functional pairing of glycans with lectins. Cell Mol Life Sci 73(10):1989-2016. https://doi.org/10. 1007/s00018-016-2163-8

154. Kaltner H, Abad-Rodriguez J, Corfield AP, Kopitz J, Gabius HJ (2019) The sugar code: letters and vocabulary, writers, editors and readers and biosignificance of functional glycan-lectin pairing. Biochem J 476(18):2623-2655. https://doi.org/10.1042/ BCJ20170853

155. Murphy PV, Romero A, Xiao Q, Ludwig A-K, Jogula S, Shilova NV, Singh T, Gabba A, Javed B, Zhang D, Medrano FJ, Kaltner H, Kopitz J, Bovin NV, Wu AM, Klein ML, Percec V, Gabius H-J (2021) Probing sulfatide-tissue lectin recognition with 
functionalized glycodendrimersomes. iScience 24(1):101919. https://doi.org/10.1016/j.isci.2020.101919

156. Miller MC, Cai C, Wichapong K, Bhaduri S, Pohl NLB, Linhardt RJ, Gabius HJ, Mayo KH (2020) Structural insight into the binding of human galectins to corneal keratan sulfate, its desulfated form and related saccharides. Sci Rep 10(1):15708. https://doi. org/10.1038/s41598-020-72645-9

157. Flores-Ibarra A, Vertesy S, Medrano FJ, Gabius HJ, Romero A (2018) Crystallization of a human galectin-3 variant with two ordered segments in the shortened N-terminal tail. Sci Rep 8(1):9835. https://doi.org/10.1038/s41598-018-28235-x

158. Vicuna L, Pardo E, Curkovic C, Doger R, Oyanadel C, Metz C, Massardo L, Gonzalez A, Soza A (2013) Galectin-8 binds to LFA-1, blocks its interaction with ICAM-1 and is counteracted by anti-Gal-8 autoantibodies isolated from lupus patients. Biol Res 46(3):275-280. https://doi.org/10.4067/S0716-9760201300 0300008

159. Zhang Z, Miller MC, Xu X, Song C, Zhang F, Zheng Y, Zhou Y, Tai G, Mayo KH (2019) NMR-based insight into galectin-3 binding to endothelial cell adhesion molecule CD146: evidence for noncanonical interactions with the lectin's CRD $\beta$-sandwich F-face. Glycobiology 29(8):608-618. https://doi.org/10.1093/ glycob/cwz036

160. Thurston TL, Wandel MP, von Muhlinen N, Foeglein A, Randow $\mathrm{F}$ (2012) Galectin 8 targets damaged vesicles for autophagy to defend cells against bacterial invasion. Nature 482(7385):414418. https://doi.org/10.1038/nature10744

161. Chauhan S, Kumar S, Jain A, Ponpuak M, Mudd MH, Kimura T, Choi SW, Peters R, Mandell M, Bruun JA, Johansen T, Deretic V (2016) TRIMs and galectins globally cooperate and TRIM16 and galectin-3 co-direct autophagy in endomembrane damage homeostasis. Dev Cell 39(1):13-27. https://doi.org/10.1016/j. devcel.2016.08.003

162. Fraser J, Simpson J, Fontana R, Kishi-Itakura C, Ktistakis NT, Gammoh N (2019) Targeting of early endosomes by autophagy facilitates EGFR recycling and signalling. EMBO Rep 20(10):e47734. https://doi.org/10.15252/embr.201947734

163. Jia J, Claude-Taupin A, Gu Y, Choi SW, Peters R, Bissa B, Mudd MH, Allers L, Pallikkuth S, Lidke KA, Salemi M, Phinney B, Mari M, Reggiori F, Deretic V (2020) Galectin-3 coordinates a cellular system for lysosomal repair and removal. Dev Cell 52(1):69-87 e68. https://doi.org/10.1016/j.devcel.2019.10.025

164. Kim BW, Hong SB, Kim JH, Kwon DH, Song HK (2013) Structural basis for recognition of autophagic receptor NDP52 by the sugar receptor galectin-8. Nat Commun 4:1613. https://doi.org/ 10.1038/ncomms 2606

165. Li S, Wandel MP, Li F, Liu Z, He C, Wu J, Shi Y, Randow F (2013) Sterical hindrance promotes selectivity of the autophagy cargo receptor NDP52 for the danger receptor galectin-8 in antibacterial autophagy. Sci Signal 6(261):ra9. https://doi.org/10. 1126/scisignal.2003730

166. Hughes RC (1999) Secretion of the galectin family of mammalian carbohydrate-binding proteins. Biochim Biophys Acta 1473(1):172-185. https://doi.org/10.1016/s0304-4165(99) 00177-4

167. Kutzner TJ, Higuero AM, Sussmair M, Kopitz J, Hingar M, Diez-Revuelta N, Caballero GG, Kaltner H, Lindner I, AbadRodriguez J, Reusch D (1864) Gabius HJ (2020) How presence of a signal peptide affects human galectins-1 and -4: clues to explain common absence of a leader sequence among adhesion/ growth-regulatory galectins. Biochim Biophys Acta Gen Subj 1:129449. https://doi.org/10.1016/j.bbagen.2019.129449

168. Gordon-Alonso M, Hirsch T, Wildmann C, van der Bruggen $P$ (2017) Galectin-3 captures interferon- $\gamma$ in the tumor matrix reducing chemokine gradient production and T-cell tumor infiltration. Nat Commun 8(1):793. https://doi.org/10.1038/ s41467-017-00925-6

169. Blouin CM, Hamon Y, Gonnord P, Boularan C, Kagan J, Viaris de Lesegno C, Ruez R, Mailfert S, Bertaux N, Loew D, Wunder C, Johannes L, Vogt G, Contreras FX, Marguet D, Casanova JL, Gales C, He HT, Lamaze C (2016) Glycosylation-dependent IFN- $\gamma \mathrm{R}$ partitioning in lipid and actin nanodomains is critical for JAK activation. Cell 166(4):920-934. https://doi.org/10.1016/j. cell.2016.07.003

170. Miller MC, Ludwig AK, Wichapong K, Kaltner H, Kopitz J, Gabius HJ, Mayo KH (2018) Adhesion/growth-regulatory galectins tested in combination: evidence for formation of hybrids as heterodimers. Biochem J 475(5):1003-1018. https://doi.org/10. 1042/BCJ20170658

171. Miller MC, Nesmelova IV, Daragan VA, Ippel H, Michalak M, Dregni A, Kaltner H, Kopitz J, Gabius HJ, Mayo KH (2020) Pro4 prolyl peptide bond isomerization in human galectin-7 modulates the monomer-dimer equilibrum to affect function. Biochem $\mathrm{J}$ 477(17):3147-3165. https://doi.org/10.1042/BCJ20200499

172. Nesmelova IV, Pang M, Baum LG, Mayo KH (2008) ${ }^{1} \mathrm{H},{ }^{13} \mathrm{C}$, and ${ }^{15} \mathrm{~N}$ backbone and side-chain chemical shift assignments for the $29 \mathrm{kDa}$ human galectin-1 protein dimer. Biomol NMR Assign 2(2):203-205. https://doi.org/10.1007/s12104-008-9121-9

173. Ippel H, Miller MC, Vertesy S, Zheng Y, Canada FJ, Suylen D, Umemoto K, Romano C, Hackeng T, Tai G, Leffler H, Kopitz J, Andre S, Kubler D, Jimenez-Barbero J, Oscarson S, Gabius HJ, Mayo KH (2016) Intra- and intermolecular interactions of human galectin-3: assessment by full-assignment-based NMR. Glycobiology 26(8):888-903. https://doi.org/10.1093/glycob/ cww021

174. Crump MP, Gong JH, Loetscher P, Rajarathnam K, Amara A, Arenzana-Seisdedos F, Virelizier JL, Baggiolini M, Sykes BD, Clark-Lewis I (1997) Solution structure and basis for functional activity of stromal cell-derived factor-1; dissociation of CXCR4 activation from binding and inhibition of HIV-1. EMBO J 16(23):6996-7007. https://doi.org/10.1093/emboj/16.23.6996

175. Gozansky EK, Louis JM, Caffrey M, Clore GM (2005) Mapping the binding of the N-terminal extracellular tail of the CXCR4 receptor to stromal cell-derived factor-1 $\alpha$. J Mol Biol 345(4):651-658. https://doi.org/10.1016/j.jmb.2004.11.003

176. Eckardt V, Miller MC, Blanchet X, Duan R, Leberzammer J, Duchene J, Soehnlein O, Megens RT, Ludwig AK, Dregni A, Faussner A, Wichapong K, Ippel H, Dijkgraaf I, Kaltner H, Doring Y, Bidzhekov K, Hackeng TM, Weber C, Gabius HJ, von Hundelshausen P, Mayo KH (2020) Chemokines and galectins form heterodimers to modulate inflammation. EMBO Rep 21(4):e47852. https://doi.org/10.15252/embr.201947852

177. Hsu DK, Zuberi RI, Liu FT (1992) Biochemical and biophysical characterization of human recombinant IgE-binding protein, an S-type animal lectin. J Biol Chem 267(20):14167-14174

178. Herrmann J, Turck CW, Atchison RE, Huflejt ME, Poulter L, Gitt MA, Burlingame AL, Barondes SH, Leffler H (1993) Primary structure of the soluble lactose binding lectin L-29 from rat and dog and interaction of its non-collagenous proline-, glycine-, tyrosine-rich sequence with bacterial and tissue collagenase. J Biol Chem 268(35):26704-26711. https://doi.org/10.1016/ S0021-9258(19)74370-1

179. Ochieng J, Fridman R, Nangia-Makker P, Kleiner DE, Liotta LA, Stetler-Stevenson WG, Raz A (1994) Galectin-3 is a novel substrate for human matrix metalloproteinases-2 and -9 . Biochemistry 33(47):14109-14114. https://doi.org/10.1021/bi002 $51 \mathrm{a} 020$

180. Talaga ML, Fan N, Fueri AL, Brown RK, Bandyopadhyay P, Dam TK (2016) Multitasking human lectin galectin-3 interacts with sulfated glycosaminoglycans and chondroitin sulfate 
proteoglycans. Biochemistry 55(32):4541-4551. https://doi.org/ 10.1021/acs.biochem.6b00504

181. Flotte TJ, Springer TA, Thorbecke GJ (1983) Dendritic cell and macrophage staining by monoclonal antibodies in tissue sections and epidermal sheets. Am J Pathol 111(1):112-124

182. Peranzoni E, Lemoine J, Vimeux L, Feuillet V, Barrin S, Kantari-Mimoun C, Bercovici N, Guerin M, Biton J, Ouakrim H, Regnier F, Lupo A, Alifano M, Damotte D, Donnadieu E (2018) Macrophages impede CD8 T cells from reaching tumor cells and limit the efficacy of anti-PD-1 treatment. Proc Natl Acad Sci USA 115(17):E4041-E4050. https://doi.org/10.1073/pnas.17209 48115
183. Ludwig AK, Kaltner H, Kopitz J, Gabius HJ (2019) Lectinology 4.0: altering modular (ga)lectin display for functional analysis and biomedical applications. Biochim Biophys Acta Gen Subj 1863(5):935-940. https://doi.org/10.1016/j.bbagen.2019.03.005

184. Deshauer C, Morgan AM, Ryan EO, Handel TM, Prestegard JH, Wang X (2015) Interactions of the chemokine CCL5/RANTES with medium-sized chondroitin sulfate ligands. Structure 23(6):1066-1077. https://doi.org/10.1016/j.str.2015.03.024

Publisher's Note Springer Nature remains neutral with regard to jurisdictional claims in published maps and institutional affiliations. 